\title{
High-resolution provenance of desert dust deposited on Mt. Elbrus, Caucasus in 2009-2012 using snow pit and firn core records
}

\author{
S. Kutuzov ${ }^{1,2}$, M. Shahgedanova ${ }^{1}$, V. Mikhalenko ${ }^{2}$, P. Ginot ${ }^{3,4}$, I. Lavrentiev ${ }^{2}$, and S. Kemp \\ ${ }^{1}$ Department of Geography and Environmental Science and Walker Institute for Climate System Research, University of \\ Reading, Reading, RG6AB, UK \\ ${ }^{2}$ Laboratory of Glaciology, Institute of Geography, Russian Academy of Science, Moscow, Russia \\ ${ }^{3}$ IRD/Univ. Grenoble Alpes/CNRS/Univ. Savoie/INPG/IFSTTAR/CNRM, Observatoire des Sciences de 1'Univers de \\ Grenoble (OSUG) UMS222, Grenoble, 38041, France \\ ${ }^{4}$ Univ. Grenoble Alpes/CNRS, Laboratoire de Glaciologie et Géophysique de l'Environnement (LGGE) UMR5183, \\ Grenoble, 38041, France
}

Correspondence to: S. Kutuzov (s.kutuzov@reading.ac.uk)

Received: 26 March 2013 - Published in The Cryosphere Discuss.: 23 April 2013

Revised: 29 July 2013 - Accepted: 11 August 2013 - Published: 24 September 2013

\begin{abstract}
The first record of dust deposition events on Mt. Elbrus, Caucasus Mountains derived from a snow pit and a shallow firn core is presented for the 2009-2012 period. A combination of isotopic analysis, SEVIRI red-greenblue composite imagery, MODIS atmospheric optical depth fields derived using the Deep Blue algorithm, air mass trajectories derived using the HYSPLIT model and analyses of meteorological data enabled identification of dust source regions with high temporal (hours) and spatial (ca. 20-100 km) resolution. Seventeen dust deposition events were detected; fourteen occurred in March-June, one in February and two in October. Four events originated in the Sahara, predominantly in northeastern Libya and eastern Algeria. Thirteen events originated in the Middle East, in the Syrian Desert and northern Mesopotamia, from a mixture of natural and anthropogenic sources. Dust transportation from Sahara was associated with vigorous Saharan depressions, strong surface winds in the source region and mid-tropospheric southwesterly flow with daily winds speeds of $20-30 \mathrm{~m} \mathrm{~s}^{-1}$ at $700 \mathrm{hPa}$ level. Although these events were less frequent than those originating in the Middle East, they resulted in higher dust concentrations in snow. Dust transportation from the Middle East was associated with weaker depressions forming over the source region, high pressure centred over or extending towards the Caspian Sea and a weaker southerly or southeasterly flow towards the Caucasus Mountains with daily wind speeds of $12-18 \mathrm{~m} \mathrm{~s}^{-1}$ at $700 \mathrm{hPa}$ level. Higher concentra-
\end{abstract}

tions of nitrates and ammonium characterised dust from the Middle East deposited on Mt. Elbrus in 2009 indicating contribution of anthropogenic sources. The modal values of particle size distributions ranged between $1.98 \mu \mathrm{m}$ and $4.16 \mu \mathrm{m}$. Most samples were characterised by modal values of 2.0 $2.8 \mu \mathrm{m}$ with an average of $2.6 \mu \mathrm{m}$ and there was no significant difference between dust from the Sahara and the Middle East.

\section{Introduction}

Ice and firn cores provide a valuable proxy data on climatic and environmental changes including changes in aridity as documented by mineral dust deposited on glacier surface and trapped in ice (Legrand and Mayewski, 1997; Thompson et al., 2006). Present and past records of dust, stored in glacier ice, provide valuable information on frequency of deposition events, sources and atmospheric pathways of mineral dust which can be used to assess changes in atmospheric circulation, environments in source regions and validate climate models (Xu et al., 2010; Wu et al., 2013). Most long-term dust records were obtained from the Greenland and Antarctic ice cores (e.g. Delmonte et al., 2002; Petit et al., 1999; Ruth, 2003). These records characterise global and long-range dust transportation patterns and changes on the millennial time scales. High mountain regions in low and middle latitudes 
located in relative proximity to dust source regions provide an opportunity to assess variability in dust emissions and atmospheric circulation on regional scale. Transportation of dust from the Sahara to the glaciers in the European Alps is well studied (De Angelis and Gaudichet, 1991; Collaud Coen et al., 2004; Schwikowski et al., 1999, 1995; Sodemann et al., 2006; Thevenon et al., 2009, 2012; Wagenbach and Geis, 1989). A number of studies examined variability in mineral dust transportation and deposition on glaciers of Central Asia (Dong et al., 2009; Kreutz et al., 2001; Thompson et al., 1989; Wake et al., 1994; Yang et al., 2006), Himalayas and Tibetan Plateau (Kaspari et al., 2009; Wu et al., 2009, 2013; Xu et al., 2010) and the Altai (Olivier et al. 2003; 2006).

One glacierized region, which is affected by desert dust deposition but has not been studied in this respect, is the Caucasus Mountains located between the Black and the Caspian Seas (Fig. 1) in proximity to the arid regions of the Middle East and on the track of Saharan depressions (Hannachi et al., 2011). The Caucasus accommodates about 2000 glaciers covering approximately $1600 \mathrm{~km}^{2}$ whose retreat intensified since the 1980s with a combined glaciated area loss of $10 \%$ between 1985 and 2000 (Stokes et al., 2006). While there was research on regional snow chemistry (e.g. Rototaeva et al., 1998; 1999), characteristics of mineral dust and its provenance was studied in relation to a single dust deposition event, which occurred on Mt. Elbrus on 5 May 2009 (Kokkalis et al., 2012; Shahgedanova et al., 2013). Using this deposition event, Shahgedanova et al. (2013) developed a methodology for high temporal (ca. hours) and spatial (ca. 50-100 km) resolution "provenancing" of recent dust deposition events recorded in snow pack and firn and shallow ice cores using satellite products developed specifically for tracking desert dust in the atmosphere, atmospheric trajectory modelling and analysis of meteorological data.

The main objective of this paper is to examine a four-year (2009-2012) record of dust deposition events on Mt. Elbrus, northern Caucasus, Russia using snow pit and shallow firn core data. The specific objectives are to (i) date dust deposition events and establish their source regions building on the methodology proposed by Shahgedanova et al. (2013); (ii) characterise meteorological conditions leading to dust deposition; (iii) characterise physical and, for part of the record, chemical properties of deposited dust; and (iv) attempt to establish links between physical and chemical properties of dust and its source regions.

Mt. Elbrus presents an ideal location for the examination of dust trapped in snow, firn and glacier ice because its high elevation (5642 $\mathrm{m}$ above sea level; a.s.l.; Fig. 1b) ensures solid precipitation throughout the year and absence of significant seasonal melt above approximately $4600 \mathrm{~m}$ a.s.l. (Mikhalenko et al., 2005). Free tropospheric conditions prevail over $4000 \mathrm{~m}$ in winter and spring and, consequently, these elevations are not reached by local polluted air masses and aerosol deposition is associated with long-range transport.

\section{Data and methods}

\subsection{Collection of samples}

Two sets of samples were collected on the Western Plateau on Mt. Elbrus $\left(43^{\circ} 20^{\prime} 53.9^{\prime \prime} \mathrm{N}, 42^{\circ} 25^{\prime} 36.0^{\prime \prime} \mathrm{E}\right)$ at an elevation of 5115 m a.s.l. (Fig. 1b) on 7 September 2009 and on 26 June 2012. For logistical reasons, different methodologies were used to collect samples in 2009 and 2012 predetermining different methods of sample analysis.

In June 2009, twenty three snow samples were collected from a snow pit containing four visible yellow-brown layers of dust. Samples were collected using a pre-cleaned shovel and polyethylene gloves along the depth of the snow pit and included snow with and without dust. The top $10 \mathrm{~cm}$ of snow were discarded to avoid potential contamination. Snow without visible layers of dust was sampled at $10 \mathrm{~cm}$ intervals. The thickness of four dust-containing layers detected in the snow pit was less than $10 \mathrm{~cm}$ on all but one occasion and these layers were sampled at different intervals according to their depth. The collected samples were kept frozen in the WhirlPak bags and used for analyses for concentration of major water-soluble ions, dust particle size distribution and stable isotopes of oxygen and hydrogen.

In June 2012, a $12 \mathrm{~m}$ firn core was extracted at the same location. In this core, thirteen dust layers were visually identified and sections of the core containing dust layers were cut out. The outer layers of the core (approximately $1-2 \mathrm{~cm}$ ) were removed using a pre-cleaned plastic scoop to avoid contamination. The samples were melted and the melt water was filtered using $0.2 \mu \mathrm{m}$ Millipore isopore membrane filters. The filters were placed in the sterile Petri dishes for transportation. In addition, 111 snow samples were taken from the core at $10 \mathrm{~cm}$ intervals for isotopic analysis.

Both the snow pit profile and the shallow core were examined for the occurrence of thin crusts of ice which form on snow surface in late spring-early summer in response to increasing insolation and serve as stratigraphic markers allowing one to establish in which month or season dust deposition events occurred. Measurements of snow weight and volume in the snow pit and in the core were made alongside the snow pit and shallow core sampling in order to calculate snow and firn density which was calculated by dividing the weight of snow or firn by its volume.

\subsection{Isotopic analysis}

Both snow pit and shallow core samples were analysed for deuterium-hydrogen $(\mathrm{D} / \mathrm{H})$ and oxygen $\left({ }^{18} \mathrm{O} /{ }^{16} \mathrm{O}\right)$ isotope ratios using Picarro L1102-i instrument in the Climate and Environment Research Laboratory (CERL), Arctic and Antarctic Research Institute, St. Petersburg, Russia. 


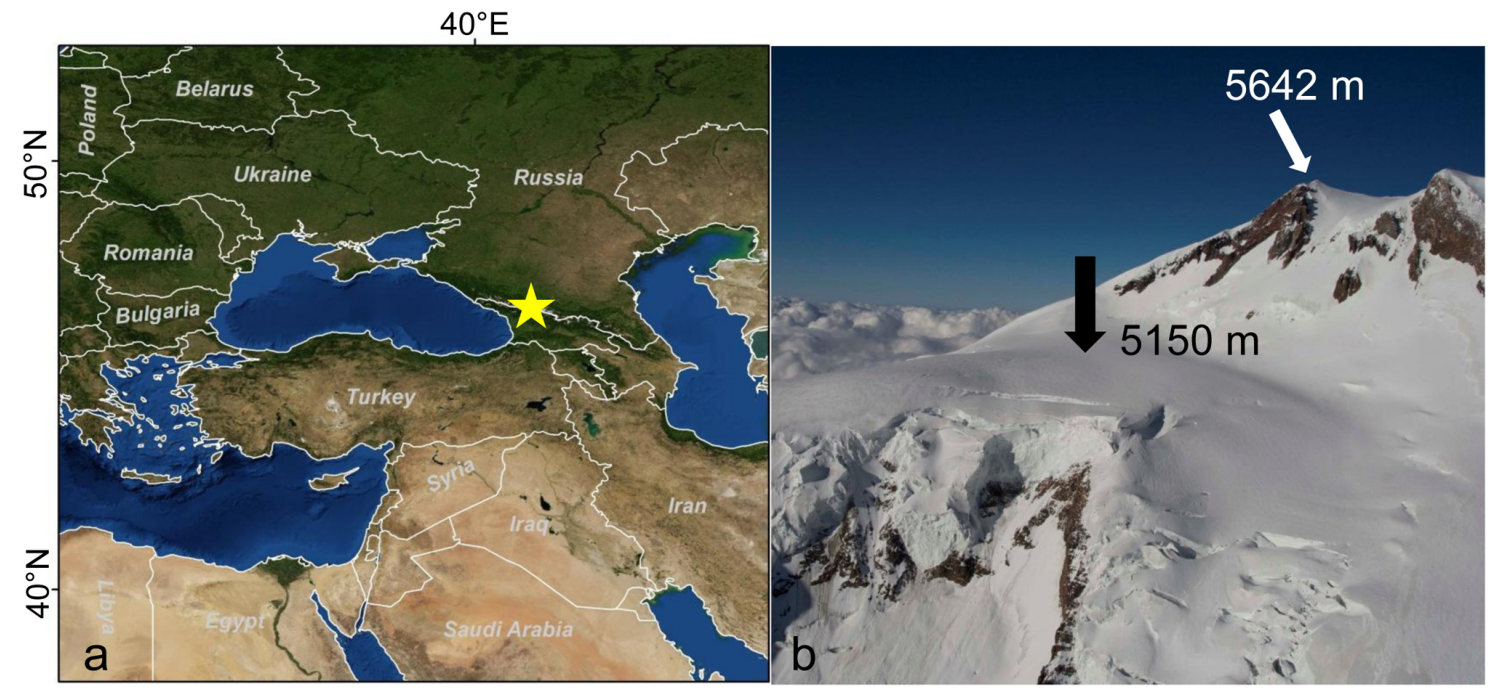

Fig. 1. (a) Location of study area and (b) snow sample collection and shallow core extraction site (indicated by the black arrow). The highest elevation (the West Elbrus summit) is indicated by the white arrow.

To estimate precision of the measurements and to minimise memory effect associated with continuous measurements, the instrument was calibrated on a regular basis against isotopic standards V-SMOW, GISP and SLAP provided by the International Atomic Energy Agency (IAEA). The estimated accuracy was $\pm 0.067 \%$ o for oxygen isotope $\left(\delta^{18} \mathrm{O}\right)$ and $\pm 0.31 \%$ o for deuterium $(\delta \mathrm{D})$. The CERL laboratory working standard SPB was measured repeatedly following analysis of every 5 samples. The $\delta^{18} \mathrm{O}$ and $\delta \mathrm{D}$ values were expressed in \%o units relative to the V-SMOW value.

\subsection{Particle size distribution}

Two different methods, predetermined by different ways of sampling dust from the snow pit and the shallow core, were used. The snow samples with and without visible dust layers obtained in 2009 were analysed using Coulter Counter Multisizer 3 (CCM) with 300 channels, set up in the class-100 clean room at the Laboratory of Glaciology and Geophysics of the Environment (LGGE), Grenoble, France. The instrument was set to detect particles with equivalent spherical diameter (Reid et al., 2003) from $1.0 \mu \mathrm{m}$ to $30.0 \mu \mathrm{m}$ producing particle counts per $10^{-3} \mathrm{~L}$ and numerical frequency distributions as well as total particle mass expressed in parts per billion (ppb). The liquid sample in a covered accuvette was turned three times for dust homogenization, and analysed in the following $30 \mathrm{~s}$ to avoid large particles settling. This procedure was used with the same timing for all the samples. However, according to the measured dust size distribution in samples, the number of larger particles $(>10 \mu \mathrm{m})$ was reduced so that settling does not affect a large number of particles. Each size distribution represented an average of at least three independent measurements of the same sample. Background distributions were characterised using snow samples, which did not contain visible dust layers. Particle mass concentrations $\left(\mu \mathrm{g} \mathrm{kg}^{-1}\right)$ were obtained from the volume distributions using mean particle density of $2.5 \mathrm{~g} \mathrm{~cm}^{-3}$.

Dust samples obtained from the shallow core in 2012 were analysed using scanning electron microscope (SEM) Cambridge 360 Stereoscan at the Centre for Advanced Microscopy (CfAM), the University of Reading, UK. Sections of filters containing mineral particles were cut out and coated with carbon adhesive layer prior to the analysis. In order to cover the whole size range of dust particles between $0.2 \mu \mathrm{m}$ and $30 \mu \mathrm{m}$, images of each sample were taken at 1000, 5000 and 10000 magnifications. Scandium software was used for analysis: For every dust sample, over 2000 particles were manually digitised and their geometric characteristics were automatically measured by the software. Manual digitisation was used to avoid the problem of particle overlapping.

The CCM and SEM data were obtained in the format of numerical distribution and had different cut-off points of $1.0 \mu \mathrm{m}$ and $0.2 \mu \mathrm{m}$ (predetermined by the pore size of the filters) respectively. Both CCM and SEM measurements were transformed to distributions by volume whereby accumulated particles in each diameter bin were converted into accumulated volumes following Ruth et al. (2003). For each individual particle, volume was calculated as

$V_{i}=\frac{4 \pi}{3}\left(\frac{\overline{d_{i}}}{2}\right)^{2}$

where $d_{i}$ is a characteristic diameter of each bin calculated as square root of a product of the upper and lower bin boundaries. Accumulated volumetric frequency was calculated as a product of characteristic mean single particle volume and a number of particles in each bin. Volumetric distribution function is sensitive to the choice of $d$. For fitting procedure, the 
300 channels used by CCM were reduced to 50 bins and the same bins were used for SEM data. Following data transformation, log-normal size distribution function was fitted to the original data following Steffensen (1997), Delmonte et al. (2002) and Ruth at al. (2003).

\subsection{Water-soluble ions}

The snow pit samples, including four samples containing dust, were analysed for soluble ions using Dionex Dual ICS3000 ion chromatography system in the class- 100 clean room at the LGGE Laboratory. Chemical analysis of cations $\left(\mathrm{Li}^{+}\right.$, $\mathrm{Na}^{+}, \mathrm{NH}_{4}^{+}, \mathrm{K}^{+}, \mathrm{Mg}^{2+}, \mathrm{Mn}^{2+}, \mathrm{Ca}^{2+}$ ) were performed using CG16 and CS16 cations separator column and a CSRS300 conductivity suppressor (Dionex) and isocratic $27 \mathrm{mM}$ methanesulfonic acid as eluent. Anion $\left(\mathrm{F}^{-}, \mathrm{CHOO}^{-}, \mathrm{Cl}^{-}\right.$, $\mathrm{NO}_{3}^{-}, \mathrm{SO}_{4}^{2-}, \mathrm{C}_{24}^{2-}$ ) analysis was performed using a AG11$\mathrm{HC}$ and AS11-HC columns and ASRS-300 suppressor, applying a gradient elution $(0.3-30 \mathrm{mM} \mathrm{KOH})$.

\subsection{Dating and "provenancing" dust deposition events}

Dust deposition events were dated and "provenanced" using methodology outlined in Shahgedanova et al. (2013) in three iterations utilising independent techniques and datasets. Firstly, visual examination of snow and shallow core profiles for dust layers together with isotopic analysis and position of the dust layers in relation to ice crusts, enabled determination of the approximate (i.e. month) timing of dust deposition events. Secondly, examination of the NCEP/NCAR reanalysis (Kalnay et al., 1996) and local meteorological data together with the Moderate Resolution Imaging Spectroradiometer (MODIS) atmospheric optical depth (AOD) (Hsu et al., 2006) data enabled dating dust deposition events to a precision of specific days and establishing broad source regions of the dust (e.g. northern Sahara or Middle East). Thirdly, Spinning Enhanced Visible and Infra-Red Imager (SEVIRI) on board the Meteosat Second Generation (MSG) red-green-blue (RGB) composite imagery and HYSPLIT atmospheric trajectory model (Draxler and Rolph, 2013; http: //ready.arl.noaa.gov/HYSPLIT.php) were used for high temporal (hours) and spatial (ca. 20-100 km) resolution "provenancing" of desert dust.

\subsubsection{Meteorological and back trajectory data}

Meteorological conditions conducive to dust entrainment, transportation and deposition were examined using NCEP/NCAR reanalysis data (Kalnay et al., 1996) including sea level pressure (SLP), geopotential height and vector wind data at $700 \mathrm{hPa}$ isobaric surface, surface and boundary layer wind speeds obtained from the National Oceanic and Atmospheric Administration (NOAA; http://www.esrl.noaa.gov/ $\mathrm{psd} / \mathrm{data} /$ ) and station measurements of air temperature, precipitation, wind speed, visibility and reports of specific meteorological events such as dust storms, blowing sand, reduc- tion in visibility and unusual, yellow colour of precipitation. The $700 \mathrm{hPa}$ vector wind fields serve as a good indicator of potential dust transportation to the Caucasus (Shahgedanova et al., 2013). Data on surface and boundary layer wind speed in the potential source regions compared with the threshold for dust mobilisation defined by Chomette et al. (1999) as 7-9 $\mathrm{m} \mathrm{s}^{-1}$ confirmed potential for dust entrainment. Meteorological conditions in the vicinity of Mt. Elbrus were evaluated using data from the Terskol weather station located $12 \mathrm{~km}$ southeast of the Western Plateau at $2141 \mathrm{~m}$ a.s.l.

For each dust deposition event, twenty-seven member ensembles of three-dimensional trajectories were calculated using HYSPLIT model run with the Global Data Assimilation System (GDAS) meteorological input (Draxler and Rolph, 2013; http://ready.arl.noaa.gov/HYSPLIT.php). HYSPLIT has horizontal resolution of $1^{\circ}$. Each member of the trajectory ensemble is calculated by offsetting meteorological data by a fixed grid factor (one meteorological grid point in the horizontal and 0.01 sigma unit (approximately $250 \mathrm{~m}$ ) in the vertical). HYSPLIT was run in the backward mode for the Western Plateau at six-hourly intervals for the times when SEVIRI RGB images (Sect. 2.5.2) showed dust clouds passing over Mt. Elbrus. The length of each integration did not exceed $120 \mathrm{~h}$. After source regions were located with high accuracy using SEVIRI imagery, HYSPLIT was run in a forward mode using source region and time of dust storm initiation as a starting point. The differences between the end-points of back trajectories and the starting point of forward trajectories were taken as an uncertainty measure in the location of source regions using the trajectory method.

\subsubsection{Remote-sensing products}

Data from SEVIRI on board MSG satellite, positioned in a geostationary orbit at $0^{\circ} \mathrm{W}$ over the equator, were available with $15 \mathrm{~min}$ temporal resolution, which is key to high resolution "provenancing" and dating of dust events. The SEVIRI RGB composite images were produced from three thermal infrared channels, $10(12.0 \mu \mathrm{m}), 9(10.8 \mu \mathrm{m})$, and $7(8.7 \mu \mathrm{m})$, by displaying the brightness temperature differences between channels 10 and 9 as red, 9 and 7 as green and channel 9 as blue (Lensky and Rosenfeld, 2008; Schepanski et al., 2007). Spatial resolution of the RGB composites is $3 \mathrm{~km}$ at nadir decreasing to $4-7 \mathrm{~km}$ over the Middle East and the Caucasus where satellite view angle reaches $60^{\circ}$ (Roebeling et al., 2012).

On the SEVIRI RGB composite images, dust appears bright pink or magenta, clouds as orange, dark red or brown, and deserts as green-light blue. The dust effect on brightness temperature depends on the underlying surface, time of day, moisture content of the atmosphere, and altitude of dust cloud and the composite images may favour elevated layers of dust (Brindley et al., 2012; Pierangelo et al., 2004). Due to its high temporal resolution and availability throughout the day, SEVIRI RGB composites are widely used to map 
dust sources (Schepanski et al., 2007, 2009) and to examine dust plume transportation history (Bou Karam et al., 2010; Shahgedanova et al., 2013). The technique is qualitative and involves visual spotting of dust plume and tracking it either back to source region or forward to sink region by inspecting consecutive SEVIRI images with 15 min time step (Schepanski et al., 2007).

The images were downloaded from the EUMETSAT website (www.eumetsat.int) initially at $2 \mathrm{~h}$ intervals between May 2009 and June 2012. Following the preliminary analysis of meteorological data, AOD and the 2-hourly SEVIRI RGB images for dust events, additional SEVIRI images with 15 min resolution were downloaded and inspected to determine desert dust sources and reconstruct detailed transportation history.

Data from the Cloud Aerosol Lidar and Infrared Pathfinder Satellite Observation (CALIPSO) mission (http: //www-calipso.larc.nasa.gov) were used to characterise vertical distribution of dust during the event. Attenuated backscatter (reflectivity) profiles at $532 \mathrm{~nm}$ were provided by the Cloud-Aerosol Lidar with Orthogonal Polarization (CALIOP) installed on CALIPSO (Winker et al., 2003) with vertical and horizontal resolutions of $60 \mathrm{~m}$ and $12 \mathrm{~km}$ respectively. The CALIOP-derived reflectivity was used as a proxy to describe the dust layer structure as it depends on aerosol concentration and its optical properties (Bou Karam et al., 2010).

MODIS AOD at $550 \mathrm{~nm}$ derived using the Deep Blue algorithm (Hsu et al., 2006) from MODIS-Aqua collection 5.1 (http://disc.sci.gsfc.nasa.gov/giovanni/) was used. MODIS AOD fields were available daily at approximately $12 \mathrm{~h}$ local time.

\section{Results}

\subsection{Dust stratigraphy and isotopic analysis}

The stable isotope record revealed strong fluctuations in $\delta^{18} \mathrm{O}$ values with a range of $21.5 \%$, a minimum of $-27 \%$ and a maximum of $-5.5 \%$, and the record average of $-15 \%$ o (Fig. 2). These fluctuations were interpreted as seasonal cycle in which warm season values varied between $-5.5 \%$ and $-10 \%$ and cold season values varied between $-17 \%$ and $-27 \%$. The seasonal variations in $\delta^{18} \mathrm{O}$ confirmed that the shallow core extended from June 2012 to the autumn 2009. The snow pit record began 7 September 2009, when the pit was excavated and extended to the winter of 2009-2008. It is not clear whether the shallow core and the snow pit isotopic records overlap and it is possible that a short period at the end to middle of September 2009 is not represented.

The thin ice crusts, forming on the snow surface due to radiative thawing, occurred in three sections of the core and in the snow profile corresponding to the high $\delta^{18} \mathrm{O}$ values typical of the summer months (Fig. 2). Seventeen dust de-

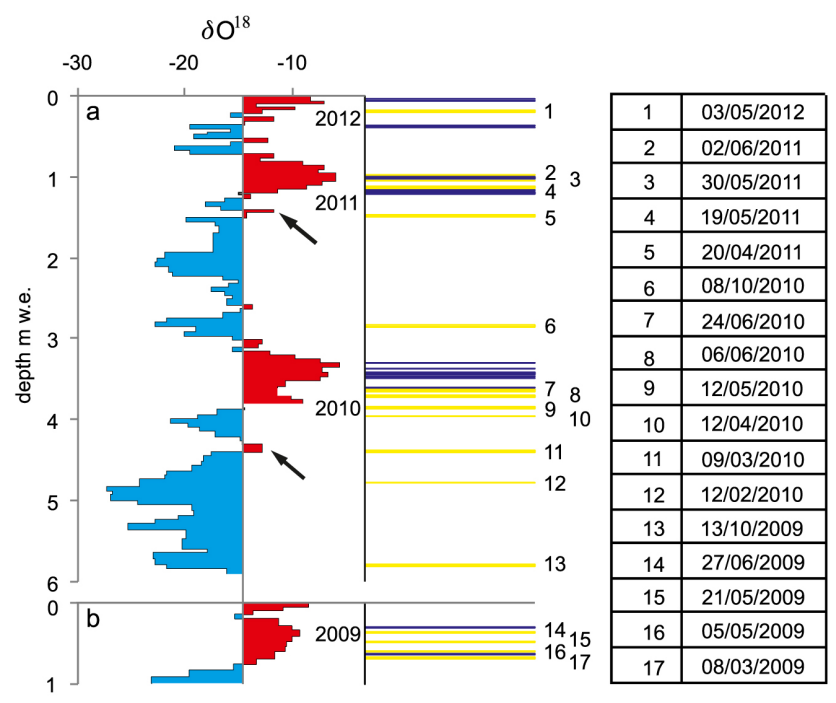

Fig. 2. Oxygen $\left(\delta^{18} \mathrm{O}\right)$ isotopic record and stratigraphy for (a) the shallow core and (b) the snow pit. Dust layers and ice crusts are shown in yellow and blue respectively. Dust deposition events are numbered from 1 (the most recent) to 17 (the earliest in the record). Dates of deposition events are shown in the table. Arrows point at the short-term increases in $\delta^{18} \mathrm{O}$ corresponding to the advection of warm air masses transporting dust (Sect. 3.1). Depth is shown in metres of water equivalent (m.w.e.)

position events were identified in the shallow core and the snow pit and their position in relation to the ice crusts and the seasonally increasing values of $\delta^{18} \mathrm{O}$ confirm that most of the dust events occurred in spring-early summer. The dust layer No. 12 was deposited at the end of winter 2010 and layers No. 13 and 6 were deposited in the autumns of 2009 and 2010. The dates were subsequently established as February 2010 and October 2009 and 2010 (Sect. 3.2).

The prominent, short-term increases in $\delta^{18} \mathrm{O}$ indicating precipitation forming in the warm air mass were observed in the springs of 2010 and 2011 coinciding with dust layers No. 11 and No. 5 (Fig. 2). Analysis of the meteorological records from Terskol revealed two episodes of warm advection and heavy snowfall on 8-10 March 2010 and 1921 April 2011. During the March episode, temperature increased from $-5.7^{\circ} \mathrm{C}$ on 8 March to $1.5^{\circ} \mathrm{C}$ on 09 of March exceeding the monthly average by $3^{\circ} \mathrm{C}$. The station registered a three-day total of $69.3 \mathrm{~mm}$ of precipitation and reported its unusual yellow colour. During the April episode, air temperature increased from -1.6 to $3.6^{\circ} \mathrm{C}$ exceeding the monthly average by $3.3^{\circ} \mathrm{C}, 40.2 \mathrm{~mm}$ of precipitation was recorded and a number regional stations reported yellowish colour of clouds.

\subsection{Chronology and "provenancing" of dust events}

The identified dust deposition events were dated and their provenance was established using a combination of methods 


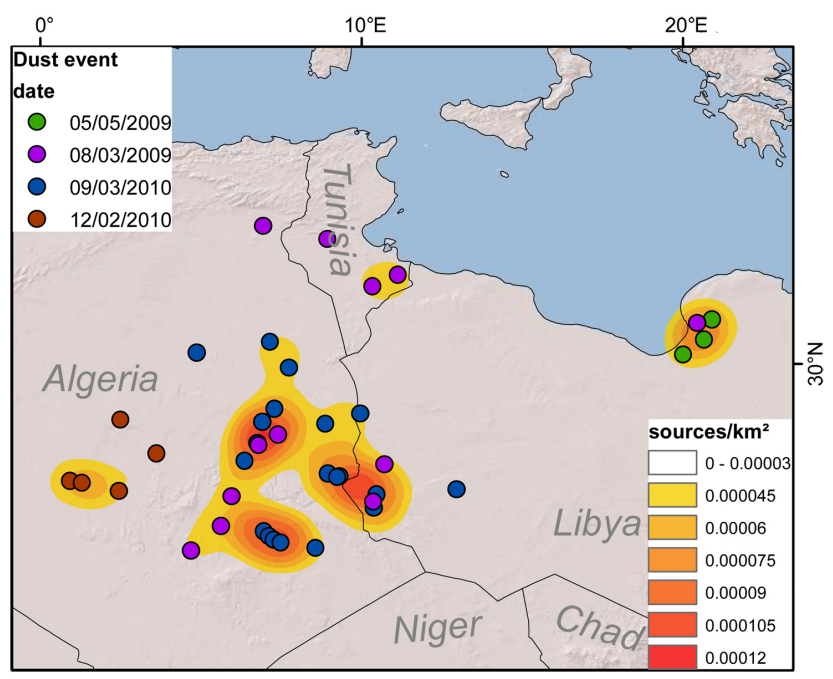

Fig. 3. The Saharan source regions of dust transported to Mt. Elbrus with dates of dust deposition. The colours represent the kernel density of the dust sources (points per unit area) as calculated in ArcGIS 10.

discussed in Sect. 2.5. Ten deposition events occurred in March-May, four events were registered in June, two events in October and one in February (Figs. 2-4). On four occasions, dust originated from the northern Sahara (Fig. 3). In thirteen cases, dust originated from the Middle East and more specifically from northern Mesopotamia (northern Syria northwestern Iraq) and the Syrian Desert (32-34 ${ }^{\circ} \mathrm{N} ; 37.5-$ 39.5 E) (Fig. 4). On 5 May 2009, the Saharan depression carrying dust travelled over the Middle East initiating additional dust uplift (Kokkalis et al., 2012; Shahgedanova et al., 2013). It is, therefore, possible to characterise dust events as Saharan, Middle Eastern and mixed and similar characterisation of dust events was suggested by Koçak et al. (2012) using the results of atmospheric mineral aerosol monitoring in 2007-2008 in the eastern Mediterranean. In both the Sahara and the Middle East, specific meteorological conditions result in dust entrainment and transport. These vary in strength and duration but not in the types of weather systems initiating dust events. Two examples demonstrate how dust deposition events were dated, their geographical provenance established and examine typical meteorological conditions leading to the uplift and transportation of dust from the Sahara and the Middle East.

A potential dust deposition event occurred on 11-13 June 2009 in addition to the events identified from the snow pit and shallow core stratigraphy. The uplift of dust from two source regions in the Middle East and its transportation to the Caucasus was identified on the SEVIRI imagery (not shown) but dust horizon was not registered in the snow pit. The evidence for weak dust deposition was provided by chemical composition of the samples and is discussed in Sect. 3.4.

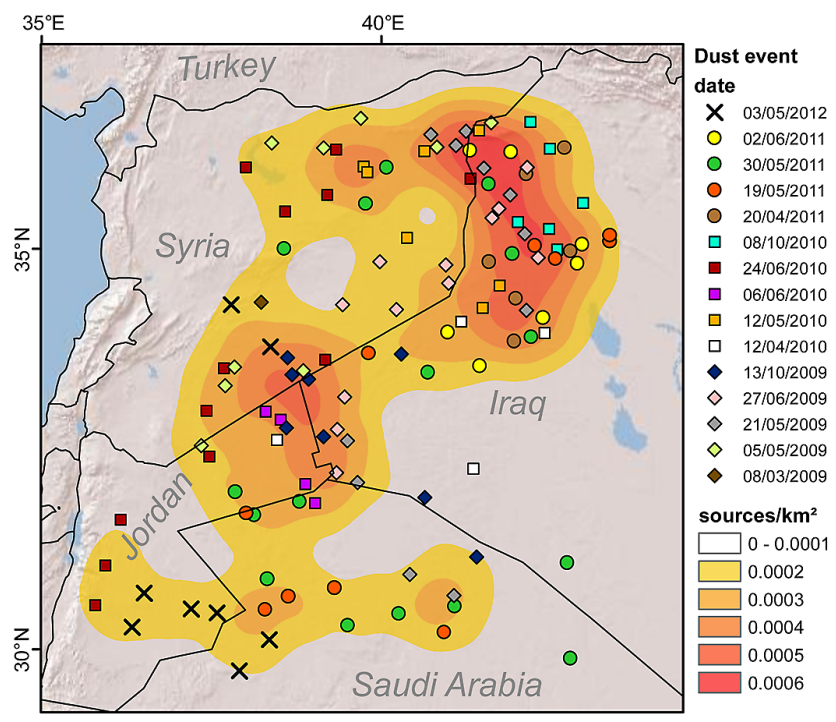

Fig. 4. The Middle Eastern source regions of dust transported to Mt. Elbrus with dates of dust deposition. The majority of dust events were traced to northern Mesopotamia (northern Syria northwestern Iraq) and the Syrian Desert (approximately $32-34^{\circ} \mathrm{N}$; $\left.37.5-39.5^{\circ} \mathrm{E}\right)$. The colours represent the kernel density of the dust sources (points per unit area) as calculated in ArcGIS 10.

\subsubsection{The Saharan event of March 2009}

Figure 3 summarises the source regions in northern Sahara supplying dust to the Caucasus. There are two main areas: (i) the foothills of the Akhdar Mountains in northeastern Libya and (ii) the foothills of the Ahaggar Mountains in eastern Algeria. Both regions were identified by Schepanski et al. (2009) as persistent dust sources active in spring. Detailed analysis of dust deposition of 5 May 2009, whereby dust originated from the foothills of the Akhdar Mountains, was provided by Shahgedanova et al. (2013). On other occasions, dust originated either from Algeria or from multiple sources including Algerian, Libyan and Tunisian sources.

The most intensive dust deposition event of all, registered between 2009 and 2012, occurred on 8 March 2009 and was contributed to by multiple sources in the northern Sahara (Fig. 3). Following this event, dust concentration in snow reached $253 \mathrm{mg} \mathrm{kg}^{-1}$ while following the intensive dust event of 5 May 2009, dust concentration was $89 \mathrm{mg} \mathrm{kg}^{-1}$. The dust uplift was initiated on 4 March by a deep trough of low pressure extending from the northern UK, across Europe to North Africa (Fig. 5a). These synoptic conditions are known to initiate the development of depressions over the northern Sahara where advection of cold air from the north is enhanced by strong temperature gradients between the Mediterranean Sea and the warm African continent (Barkan et al., 2005; Bou Karam et al., 2010; Knippertz and Todd, 2012; Schepanski et al., 2009). While NCEP/NCAR SLP re-analysis data show a deep depression 
migrating from northwestern to southeastern Europe, the UK Met Office SLP analysis charts (not shown) indicate that a depression formed over the Libyan Desert with central SLP of $1006 \mathrm{hPa}$ at 00:00 UTS on 4 March deepening to $979 \mathrm{hPa}$ on 6 March (not shown). Associated with the depression was a cold front extending from the coast through western Libya and Tunisia to Algeria and marked by a band of brown clouds on the SEVIRI RGB image (Fig. 5a). At 12:00 UTC on 4 March, the $6 \mathrm{~h}$ average wind speed exceeded $13 \mathrm{~m} \mathrm{~s}^{-1}$. Strong southwesterly flow from eastern Algeria established in the middle and the upper troposphere with the 6-hourly mean wind speeds exceeding $30 \mathrm{~m} \mathrm{~s}^{-1}$ at $700 \mathrm{hPa}$ on 4 March (not shown). While the observed conditions were similar to those leading to dust transportation on 5 May 2009 (Shahgedanova et al., 2013) as well as to other Saharan events, during the March 2009 event, a deeper depression dominated over the Mediterranean coast of Africa and stronger southwesterly mid-troposphere flow from North Africa to the Caucasus with 5-day mean wind speed in excess of $20 \mathrm{~m} \mathrm{~s}^{-1}$ persisted between 4 and 8 March (Fig. 5e). Associated with position of the centre of the depression and frontal zones were areas of strong surface wind and ascending vertical velocities. Thus, 6-hourly mean surface wind speed of $12-19 \mathrm{~m} \mathrm{~s}^{-1}$ was registered on 5 March over northeastern Libya and over the foothills of Akhdar Mountains in northeastern Libya on 6 March initiating additional dust uplift (Fig. 5b and c). Mineral dust from the latter source was transported to the Caucasus in addition to the initial dust transport from eastern Algeria. Regional meteorological station reported continuous dust storms between 4 and 7 March. The dust cloud reached Mt. Elbrus on 8 March together with the precipitation-bearing cold front. Precipitation total of $37 \mathrm{~mm}$ was recorded at the Terskol weather station on 8-9 March.

\subsubsection{The Middle Eastern event of May 2011}

The majority of dust events originating in the Middle East are associated with the development of (i) depressions over or extensions of low pressure troughs to the Middle East and Turkey in the south and (ii) high pressure in the north centred over or extending towards the Caspian Sea either from Siberia or from northern Europe. These weather systems control (i) the surface wind speeds that are sufficiently high to initiate dust uplift and (ii) formation of southerly or southeasterly flow transporting desert dust to the Caucasus. Shifts in positions of the weather systems predetermine activation of dust sources in northern Mesopotamia, the Syrian Desert or across the region (Fig. 4).

The dust event of 16-19 May 2011 (Fig. 6) typifies meteorological processes and sources of dust uplift in the region although it was characterised by a more prolonged circulation of the dust mass over the region than during other dust events and involved uplift from multiple areas including both the Syrian Desert and Mesopotamian sources. Dust entrain-

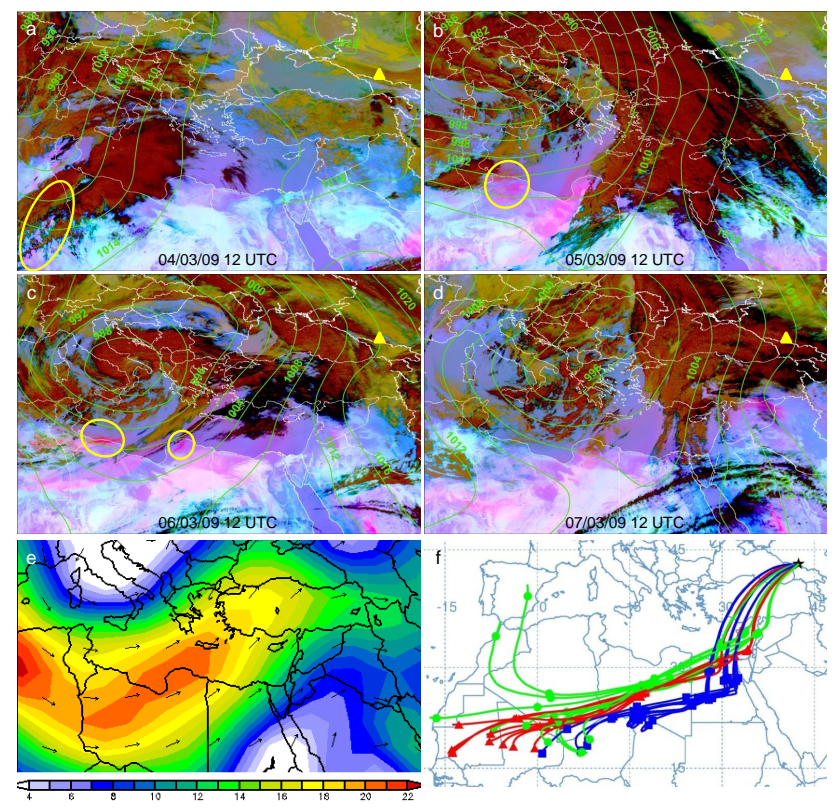

Fig. 5. (a-d) SEVIRI-derived RGB false colour composite images for 4-7 March 2009, showing dust (pink/magenta), clouds (brown/orange), and differences in surface emissivity retrieved in absence of dust or clouds (blue). Deserts appear as light greenblue. Isobars are shown as continuous green lines with SLP values (hPa). (e) Five-day (4-8 March 2009) average wind speed $\left(\mathrm{m} \mathrm{s}^{-1}\right)$ and direction at $700 \mathrm{hPa}$. (f) 4-days three-dimensional back trajectories from HYSPLIT model starting at $43.348^{\circ} \mathrm{N} ; 42.427^{\circ} \mathrm{E}$; $5000 \mathrm{~m}$ a.s.1. at 22:00 UTC on 7 March 2009. Mt. Elbrus is shown as a yellow triangle. The yellow ovals highlight areas of dust uplift.

ment was initiated by a weak depression with central pressure of $1002 \mathrm{hPa}$ forming over the Red Sea on 16 May 2011 (Fig. 6a). The initial dust uplift occurred over the northernmost Saudi Arabia and was associated with the passage of a weak front, whose position is marked on the SEVIRI image by the mid-level clouds (brown colour; Fig. 6a). The 6-hourly mean surface wind speeds, derived from NCEP/NCAR reanalysis, varied between $6-9 \mathrm{~m} \mathrm{~s}^{-1}$ but local weather stations, e.g. Gassim $\left(26.30^{\circ} \mathrm{N} ; 43.77^{\circ} \mathrm{E}\right)$ and Hail $\left(27.43^{\circ} \mathrm{N}\right.$; $\left.41.68^{\circ} \mathrm{N}\right)$, registered surface wind speeds of $10-15 \mathrm{~m} \mathrm{~s}^{-1}$ associated with the front, atmospheric dust and reduction in visibility. The migration of the low north was limited by a high pressure system centred over the northern Caspian Sea (Fig. 6a) and the dust cloud remained over the Middle East until 19 May. As the trough of low pressure gradually extended north on 17-18 May, the dust cloud migrated over Syria towards southeastern Turkey (Fig. $6 \mathrm{~b}$ and c) and elevated AOD values were registered by MODIS (Fig. 7a). A CALIOP transect for 23:00 UTC on 17 May (Fig. 7b; position of transect shown on Fig. 6b) showed strong backscattering signal indicative of the continuing dust uplift and circulation of dust over the region and its extension towards the Caucasus. In the afternoon of 18 May and on 19 May, 


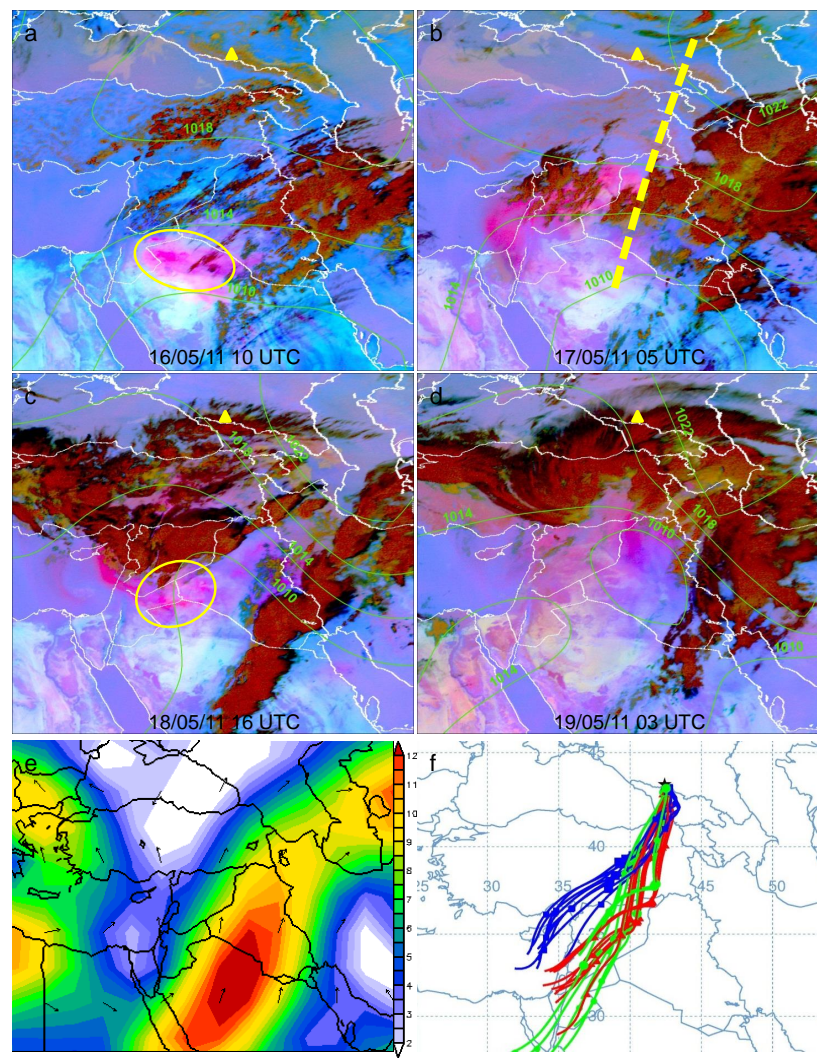

Fig. 6. (a-d) SEVIRI-derived RGB false colour composite images for 16-19 May 2011. The colour scheme, isobars and signs are as on Fig. 5. (e) Four-day (16-19 May 2009) average wind speed $\left(\mathrm{m} \mathrm{s}^{-1}\right)$ and direction at $700 \mathrm{hPa}$. (f) Two-day three-dimensional back trajectories from HYSPLIT model starting at $43.348^{\circ} \mathrm{N} ; 42.427^{\circ} \mathrm{E}$; $5000 \mathrm{~m}$ a.s.1. at 03:00 UTC on 19 May 2011. CALIOP/CALIPSO lidar transact for 17 May 2011 is shown as yellow dashed line (see Fig. 7b).

the centre of the low was positioned over Iraq (Fig. 6c and d). A zone of strong pressure gradient established between the low and the anticyclone over the Caspian Sea initiating southerly flow towards the Caucasus Mountains with four-day (16-19 May) average wind speed of $12-14 \mathrm{~m} \mathrm{~s}^{-1}$ at $700 \mathrm{hPa}$ (Fig. 6e). The southerly advection created a zone of strong baroclinicity with temperature gradients exceeding $17^{\circ} \mathrm{C}$ over $400 \mathrm{~km}$ at 00:00 UTC ( $3 \mathrm{~h}$ local time) over northern Iraq and southeastern Turkey (not shown). The frontal system marked on the SEVIRI image by thick high-level clouds (dark red) and mid-level clouds (brown) (Fig. 6c and d) was moving from the west, which in turn provided conditions for uplift of dust to the middle troposphere. Regional weather stations, e.g. Mosul $\left(36.32^{\circ} \mathrm{N} ; 43.15^{\circ} \mathrm{N}\right)$ and Kirkuk $\left(37.47^{\circ} \mathrm{N} ; 44.40^{\circ} \mathrm{N}\right)$, reported dust storms from 19:00 UTC on 18 May to 19:00 UTC 19 May and MODIS AOD values exceeded 2.15 (not shown). The dust mass reached Mt. Elbrus at 06:00 UTC on 19 May. HYSLIP trajectories (Fig. 6f) are in agreement with SEVIRI data.
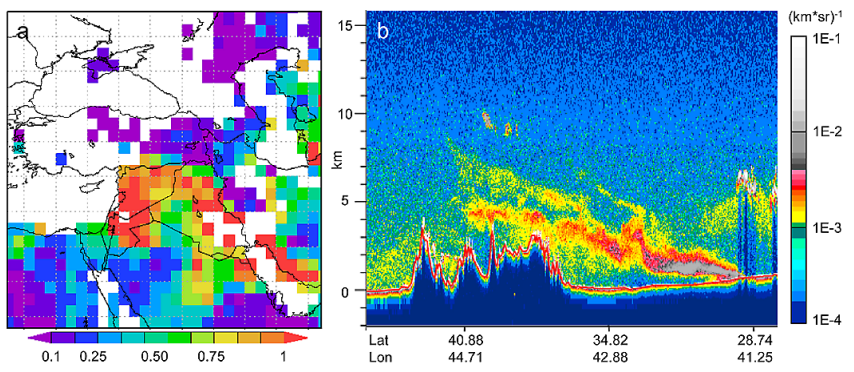

Fig. 7. (a) MODIS AOD values for 18 May 2011 and (b) CALIOP/CALIPSO transact showing attenuated backscatter coefficient $\left(\mathrm{km}^{-1} \mathrm{sr}^{-1}\right)$ profiles at $532 \mathrm{~nm}$ with $60 \mathrm{~m}$ vertical and $12 \mathrm{~km}$ horizontal resolution. The outline of the topography is shown as a solid orange line. Thick clouds appear in white and dust clouds in orange-red. Position of the transact is shown in Fig. $6 \mathrm{~b}$.

\subsection{Particle size distribution}

Statistics of the volume particle size distributions derived from analyses of seventeen dust layers are shown in Table 1. The SEM measurements cover a wider range of particle sizes than the CCM measurements. To make these statistics comparable, particles with equivalent diameter below $1 \mu \mathrm{m}$ were excluded from the calculations of statistical properties of the SEM-derived data (Table 1). While the exclusion of the small particles significantly affects particle number distribution, its effect on particle volume distribution is weak due to the small cumulative volume accounted for by these particles (see Fig. 9).

The modal values ranged between $1.98 \mu \mathrm{m}$ and $4.16 \mu \mathrm{m}$ although most samples were characterised by modal values of $2.0-2.8 \mu \mathrm{m}$ with an average of $2.6 \mu \mathrm{m}$. These values were lower than those obtained from the ice cores in central and southern Asia following the deposition of long-travelled dust (Dong et al., 2009; Wu et al., 2009, 2013; Xu et al., 2010) and are closer to those reported for the European Alps (Schwikowski et al., 1995; Thevenon et al., 2009) and the polar ice cores (Delmonte et al., 2002; Ruth et al., 2003; Steffensen, 1997).

The volume size distributions for the 2009 dust deposition events, derived from CCM analysis, are shown in Fig. 8. Close fit with log-normal curves has been achieved for all distributions although there is higher uncertainty for the fine particles. Analysis of low-concentration samples, one of which is shown in Fig. 8, revealed no systematic coarse particle mode. All four distributions derived from samples containing dust have a single mode which is usually interpreted as a single source region (Dong and $\mathrm{Li}, 2011$ ). However, during the dust deposition event of 5 May 2009, dust was transported from two different source regions, the northern Sahara and northern Mesopotamia (Shahgedanova et al., 2013; Sects. 3.2 and 3.4).

The volume distributions for 2010-2012 events are shown in Fig. 9. The number of particles analysed using SEM is 
Table 1. Characteristics of frequency distributions of dust particles ( $\mu \mathrm{m})$. Samples from 2009 and 2010-2012 were analysed using CCM and SEM respectively. Modal values $(\mu)$ and standard deviations $(\sigma)$ are given for the size distributions with the minimum equivalent particle diameter of $1 \mu \mathrm{m}$. MND and MNV are mean number and mean volume diameters respectively. Events are numbered as on Fig. 2.

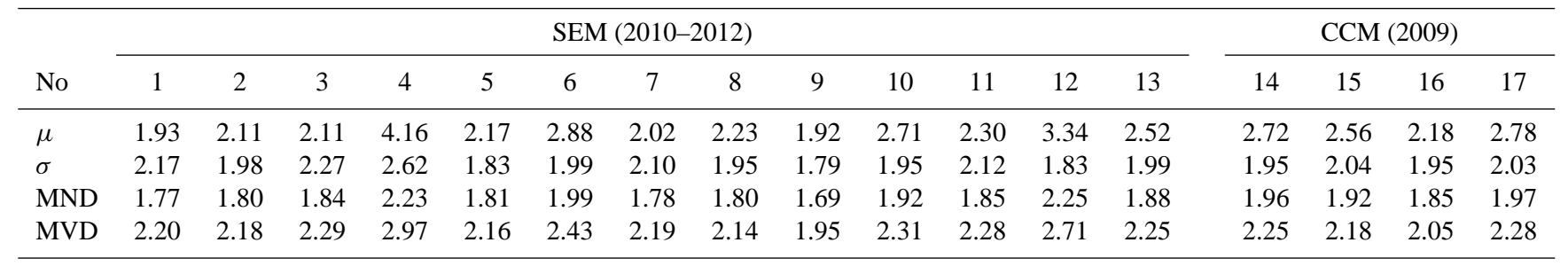

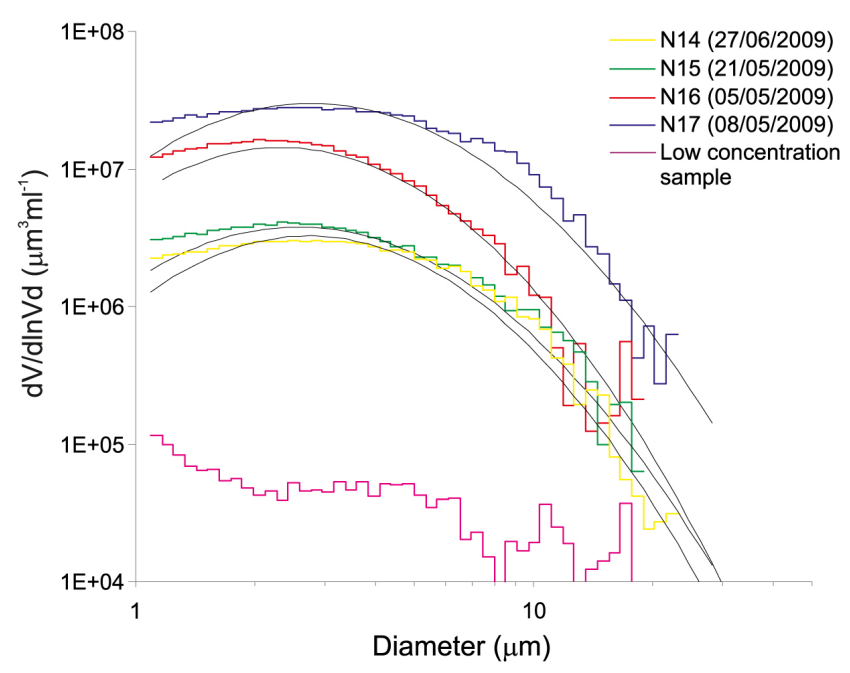

Fig. 8. Particle size distributions by volume with lognormal fits for the four dust deposition events recorded in 2009. Particle size distribution for a sample which did not contain visible dust is shown for comparison.

orders of magnitude lower than those analysed using CCM. To account for this difference, frequency distributions were presented as percentage of volume accounted for the particles in 50 bins. Similarly to 2009 , the majority of samples are characterised by the single-mode distributions. Particles with a diameter exceeding $10 \mu \mathrm{m}$ are present in all samples (Fig. 9). In the samples analysed using SEM, large particles account for a higher proportion of the volume than in the samples analysed using CCM as a result of a comparatively low number of particles used for the SEM analysis. For example, in the particle size distribution for event No. 1 (3 May 2012), a single particle with a diameter of $16 \mu \mathrm{m}$ accounted for $4 \%$ of the volume. Particles within $1-10 \mu \mathrm{m}$ range contribute $88 \pm 5 \%$ to the total volume in the thirteen samples analysed using SEM.

The dust deposition event of 19 May 2011 (No. 4) was characterised by higher frequency of larger particles. This event was characterised by the highest modal value of $4.16 \mu \mathrm{m}$ (Table 1) and particles with diameter of $10 \mu \mathrm{m}$ and larger accounted for $17 \%$ of the total volume. In addi- tion to sensitivity of particle size distributions derived from SEM analysis to the presence of large particles, high concentrations of fresh-water diatoms with equivalent diameter of $6-8 \mu \mathrm{m}$ (Fig. 10) explained the atypical size distribution and comparatively high modal values. The dust originated from several source regions in the Middle East (Sect. 3.2.2; Fig. 6) including ephemeral lakes and dry streams in Mesopotamia, which explains the presence of Cocconeis sp. diatoms whose likely ecological preference is for shallow fresh water (N. Cameron, personal communication, 2013).

\subsection{Chemical composition}

The CCM analysis, conducted on twenty three samples obtained from the 2009 snow pit, revealed four peaks in mineral dust mass in the profile (Fig. 11). The deposition of dust resulted in elevated concentrations of most ions, especially $\mathrm{Ca}^{2+}, \mathrm{Mg}^{2+}, \mathrm{K}^{+}, \mathrm{SO}_{4}^{2-}$, and $\mathrm{NO}_{3}^{-}$(Fig. 11). The average dust mass concentration for 23 samples was $18 \mathrm{~m} \mathrm{~kg}^{-1}$ and it was strongly affected by four dust deposition events. The highest concentration of total mineral dust of $253 \mathrm{mg} \mathrm{kg}^{-1}$ and $89 \mathrm{mg} \mathrm{kg}^{-1}$ characterised deposition events of 8-9 March 2009 (No. 17) and 5 May 2009 (No. 16) respectively. Although the largest amount of dust was deposited on Mt. Elbrus during the two-day deposition event on 89 March, the highest concentrations of ions characterised a short (about $2 \mathrm{~h}$ ) but intensive dust deposition event of 5 May 2009. Thus concentrations of $\mathrm{Ca}^{2+}$, a well-known indicator of desert dust in snow and ice cores (Schwikowski, 1995; Sodemann et al., 2006), reached $23 \mathrm{mg} \mathrm{kg}^{-1}$ (Fig. 11c). The total dust mass and concentrations of ions are lower in the dust layers attributed to 21 May (No. 15) and 27 June 2009 (No. 14).

$\mathrm{Na}^{+}$and $\mathrm{Cl}^{-}$are generally assumed to be of marine origin (Legrand and Mayewski, 1997). A close correlation between these ions indicates their common and predominant source while proximity to the sea-spray ion ratio of 1.8 indicates their marine origin (Schwikowski, 1995). Regression between these two species derived from all samples produced coefficient of determination $\left(R^{2}\right)$ of 0.92 with a regression slope of 1.61. The 5 May and 26 June events exhibited $\mathrm{Cl}^{-} / \mathrm{Na}^{+}$ratios that are very close to the sea-water 

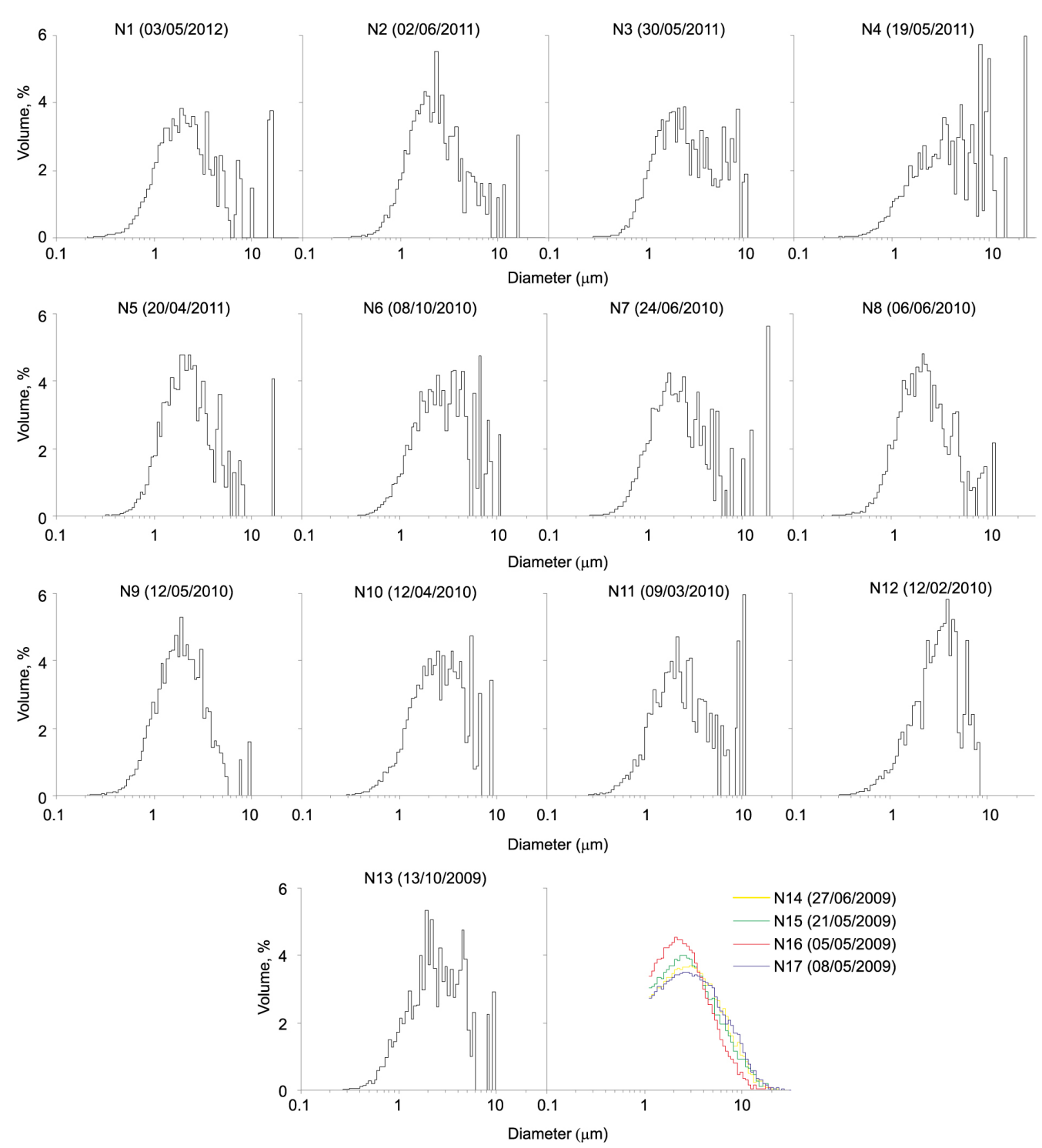

Fig. 9. Particle size distributions by volume for dust deposition events recorded between 2010 and 2012 and analysed using SEM. Particle size distributions for the 2009 events analysed using CCM are shown for comparison.

ratio which is consistent with the mixing of dust-containing air mass arriving from the Sahara and/or Middle East with air masses travelling over the Black Sea (Table 2). The lowest ratio of 1.3 characterised deposition of the Saharan dust on 8-9 March indicating a potential contribution of the halite and other terrestrial minerals to elevated $\mathrm{Na}^{+}$concentrations. This result is consisted with the reduced $\mathrm{Cl}^{-} / \mathrm{Na}^{+}$ratios reported for snow and ice in the Swiss Alps and attributed to the Saharan dust (Schwikovski, 1999) and with the origin of dust in the foothills of the Ahaggar Mountains known for the widespread occurrence of dry saline lakes.

$\mathrm{Na}^{+}$was chosen as a sea-salt tracer to evaluate sea salt contribution to the sulphate and calcium concentrations. Non-sea-salt sulphate $\left(\mathrm{nsSO}_{4}^{2-}\right)$ and calcium $\left(\mathrm{nssCa}^{2+}\right)$ composition during four dust evens was calculated from the ion ratios $\mathrm{SO}_{4}^{2-} / \mathrm{Na}^{+}$and $\mathrm{Ca}^{2+} / \mathrm{Na}^{+}$in seawater which are 0.252 and 0.038 respectively. For four dust layers sea salt, the proportion of $\mathrm{SO}_{4}^{2-}$ of marine origin accounted for $0.9 \%$ to $1.3 \%$. Sea salt contribution to $\mathrm{Ca}^{2+}$ concentrations was less than $1 \%$ in all four samples. The $\mathrm{nssSO}_{4}^{2-} / \mathrm{nssCa}^{2+}$ weight ratio for terrestrial emission of sulphate is close to that observed in soils and is 0.18 (Legrand and Mayewski, 1997; Vinogradov, 1959). Values close to this ratio, 0.19 and 0.17 , characterised the dust deposition events of 8-9 March and 5 May, which originated in the Sahara. The events of 21 May originating from two source regions in Mesopotamia and on the border between Saudi Arabia and Iraq and of 27 June originating from the border region between Iraq and Syria 
Table 2. Concentrations of major ions in the 2009 snow pit samples containing dust layers (ppb).

\begin{tabular}{lccrrrrrrr}
\hline Date (No.) & Depth (m.w.e.) & $\mathrm{Cl}^{-}$ & $\mathrm{Na}^{+}$ & $\mathrm{NO}_{3}^{-}$ & $\mathrm{SO}_{4}^{2-}$ & $\mathrm{NH}_{4}^{+}$ & $\mathrm{K}^{+}$ & $\mathrm{Mg}^{2+}$ & $\mathrm{Ca}^{2+}$ \\
\hline $27 / 06(14)$ & $0.358-0.369$ & 141 & 77 & 655 & 1714 & 220 & 95 & 78 & 5109 \\
$21 / 05(15)$ & $0.447-0.486$ & 201 & 96 & 784 & 1891 & 301 & 107 & 87 & 6604 \\
$05 / 05(16)$ & $0.594-0.602$ & 351 & 201 & 1065 & 4376 & 357 & 307 & 167 & 23609 \\
$08 / 03(17)$ & $0.670-0.689$ & 135 & 104 & 215 & 2970 & 143 & 190 & 108 & 17286 \\
\hline
\end{tabular}
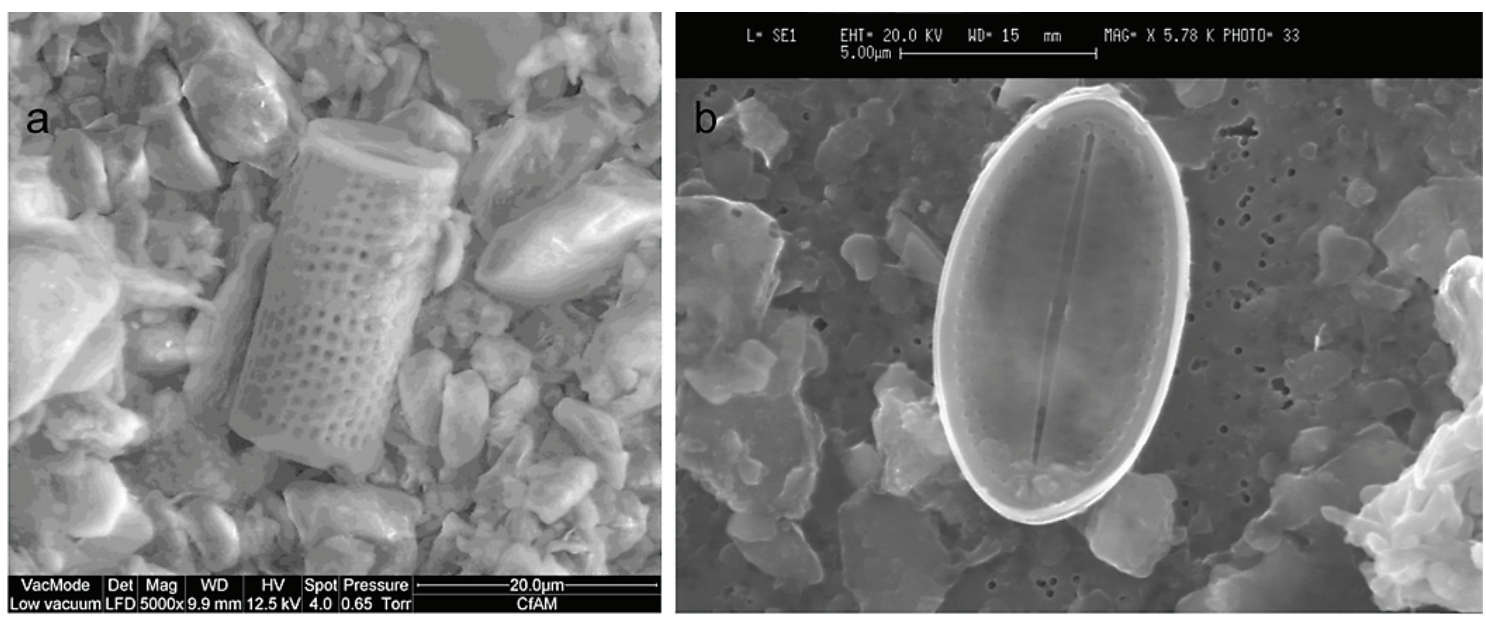

Fig. 10. Diatoms in the dust samples: (a) fresh-water Aulacoseira sp. attributed to 05 May 2009 deposition event and (b) (most likely fresh-water) Cocconeis sp. attributed to 19 May 2011 event. Classified by N. Cameron, University College London, UK.

are characterised by higher ratios of 0.34 and 0.29 . It is possible that oxidation of anthropogenic $\mathrm{SO}_{2}$ from industrial sources typical of this region might have contributed to the elevated concentrations of sulphates (Ginoux et al., 2012a). $\mathrm{NH}_{4}^{+}$species originate from biomass burning and agricultural sources such as livestock and application of fertilizers and their concentrations are known to be high over the Middle East in general and Mesopotamia in particular (Ginoux et al., 2012a). Three out of four samples of dust originating from or travelling over the Middle East were characterised by elevated concentrations of $\mathrm{NO}_{3}^{-}$and $\mathrm{NH}_{4}^{+}$while the Saharan dust deposited on 8-9 March was not.

Additional peaks in concentrations of $\mathrm{NO}_{3}^{-}, \mathrm{NH}_{4}^{+}, \mathrm{SO}_{4}^{2-}$, and to a lesser extent, $\mathrm{Mg}^{2+}$ were noted at the depth of $0.409-0.449 \mathrm{~m}$ w.e. Both the total mass and $\mathrm{Ca}^{2+}$ profiles exhibited weak increases (Fig. 11), however, no visible dust layer was detected at this depth in the snow pit. Examination of the SEVIRI imagery revealed transportation of dust from two source regions, uplifted on 11 June on the border between Syria and Jordan and on 13 June in northern Syria and Iraq, to the Caucasus (not shown). Elevated concentrations of ammonium are consistent with the extent of anthropogenic activities in the latter source region (Ginoux et al., 2012a).

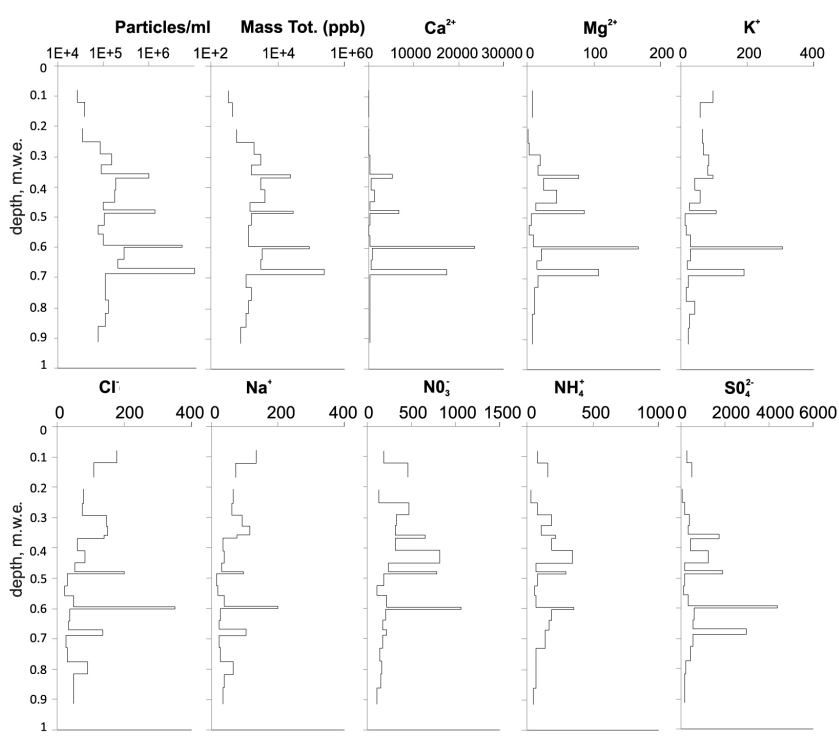

Fig. 11. Particle number, total mass, and major ion concentration recorded in the snow pit excavated in 2009. Ion concentrations are in $\mathrm{ppb}$. 


\section{Discussion}

The application of multiple, independent techniques to the examination of four-year record of dust deposition events on Mt. Elbrus enabled, for the first time, high-precision dating (ca. days) and "provenancing" (ca. 20-100 km) of dust events recorded in snow and glacier ice. Many previous studies focused on dust deposition on glaciers, however, in most dust deposition events were dated to the precision of years (e.g. Wu et al., 2013) or seasons (e.g. Kreutz et al., 2001) using traditional methods of ice core analysis. A number of studies used satellite remote sensing and back trajectory analysis and provided high-resolution dating of dust events (e.g. Collaud Coen et al., 2004; Grousset et al., 2003; Sodemann et al., 2006) especially when daily air quality observations were used. SEVIRI imagery, available at $15 \mathrm{~min}$ temporal resolution, is widely used in studies of atmospheric dust and was recently applied to dust deposition on glaciers by Shahgedanova et al. (2013). The use of SEVIRI in application to the four-year record of dust deposited on Mt. Elbrus enabled dating dust deposition events to the precision of days and, in some cases, hours and, for the first time, linked dust deposited on glaciers with their source regions with precision of a few tens of kilometres. Two main broad source regions were identified, the northern Sahara and the Middle East, and within these regions the specific areas contributing to dust deposition in the Caucasus were established (Figs. 3 and 4). While deposition of the Saharan dust on glaciers was detected in many studies (e.g. Schwikowski et al., 1995; Sodemann et al., 2006; Wagenbach and Geis, 1989), so far the Caucasus is the only region where deposition of dust originating in the Middle East was researched in detail.

Sources of dust in the Sahara have been well documented (Schepanski et al., 2007, 2009) and there is a wealth of data on geochemistry of the Saharan dust (e.g. Castillo et al., 2008; Formenti et al., 2003; Guieu, 2002). Dust sources in the Middle East are less well known and detection of dust sources using SEVIRI imagery complemented earlier studies by Walker et al. (2009) and Gerivani et al. (2011) using MODIS surface reflection imagery and by Ginoux et al. (2012b) using MODIS AOD. An important step is linking dust provenance established from remote sensing and back trajectory modelling with geochemical data despite its limitation to a single year (Sect. 4.2).

\subsection{Uncertainties in dating and "provenancing" dust deposition events}

A number of uncertainties are associated with the employed methodology. The occurrence and timing of dust deposition events were generally determined accurately using the combination of complimentary techniques including detailed visual examination of startigraphy, isotopic analysis, SEVIRI and meteorological data. An exception is weak dust deposition events which are not prominent in the snow or core profile due to the small mass of dust, but are visible on the SEVIRI imagery. An example is deposition event of 13 June 2009 which was detected not through the examination of snow profile, but through chemical analysis of soluble ions and confirmed by SEVIRI. It is possible that another weak event, not detected in the shallow core, occurred on 4 April 2011 when SEVIRI imagery shows passage of dust mass over the central Greater Caucasus. The absence of geochemical data for 2010-2012 did not allow us to confirm this deposition event. Therefore, it is important to use the proposed approach in conjunction with traditional chemical and particle size analyses for the continuum of samples. This combination was used in relation to the data obtained in 2009, but not in 2012 for logistical reasons which is a limitation of the study.

Spatial resolution of SEVIRI RGB imagery which varies between $3 \mathrm{~km}$ at nadir and $4-7 \mathrm{~km}$ over the Middle East (Roebeling et al., 2012), however, various factors preclude location of dust sources with this precision. The activation of dust sources in both regions is associated with low pressure systems and atmospheric fronts whose passage is marked by the presence of clouds. Figure 12a shows that while uplift of dust in the foothills of the Ahaggar Mountains is evident, the northern sector of this region, where eroding land surface features can be identified using surface reflectance imagery with spatial resolution of $1 \mathrm{~km}$ and higher, is obscured by cloud cover. Therefore, a larger number of sources could potentially contribute to this dust event. The same limitation characterises dust transportation from the Syrian Desert (e.g. Fig. 6) whereby contribution of sources located downwind in Syria and Iraq might not have been detected.

Cloud cover affects the ability of the method to distinguish between contribution of the Saharan and Middle Eastern sources when a dust-carrying Saharan depression passes over the Middle East initiating dust uplift that is obscured by clouds (Wilkerson, 1991; Shahgedanova et al., 2013). Both SEVIRI and Deep Blue MODIS data are affected by this limitation. CALIOP data distinguish between clouds and different types of aerosol (Winker et al., 2003), however, frequency of acquisitions over the same region limits its ability to characterise dust events. The ability of HYSPLIT trajectory data to alleviate this problem is limited because the uncertainty associated with calculation of back trajectories reaches 15$30 \%$ of the travel distance (Draxler and Rolph, 2013) and is considerably higher than that of satellite data. This limitation will not impact the European Alps and the Pyrenees which are not affected by dust transport from the Middle East.

Another potential source of uncertainty is misclassification of elevated dust plumes as fresh dust emission due to the effects of the contrast-enhancing rocky surfaces and obscuration of downstream dust plumes by raised dust from the upstream sources. Figure $12 \mathrm{~b}$ shows a bright magentacoloured plume over the dark rocks of the Tassili-N-Ajjer Desert in eastern Algeria. The intensity of the colour may be attributed to either high concentrations of mineral dust 


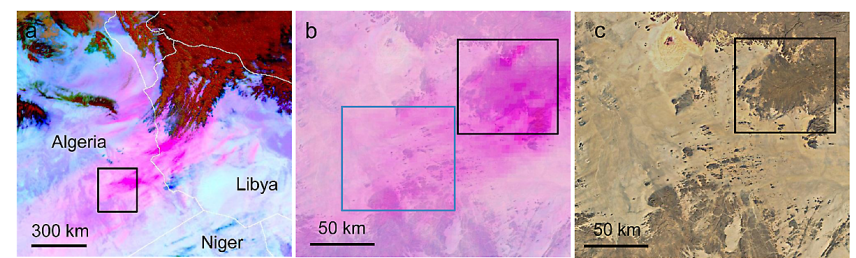

Fig. 12. (a) Dust plume over the eastern Algeria on 7 March 2010 and obscuration of dust sources located further north by clouds (dark red-brown). Black rectangle indicates area shown in (b) and (c). (b) Colour enhancement on the SEVIRI image by the underlying surface, blue rectangle shows sources of dust, black rectangle shows colour enhancement by dark-coloured rocks. (c) True-colour surface reflectance image indicating location of dark-coloured rocks with no potential dust sources.

typical of recent emission or to the false enhancement by the underlying surface. Rocky desert surfaces in particular can appear purple on SEVIRI imagery due to their high emissivity in the $8.7 \mu \mathrm{m}$ channel causing potential confusion with airborne dust (Banks and Brindley, 2013). Further examination of the high-resolution imagery confirms the absence of erodible areas serving as potential dust sources in this location (Fig. 12c). To avoid false detection, the consecutive images with $15 \mathrm{~min}$ resolution were examined and dust plumes were traced to their point of origin. The false enhancement is typical or early spring and early morning hours (Banks and Brindley, 2013) when both seasonal and diurnal maxima in dust activation occur (Schepanski et al., 2009).

A combination of Figs. 4 and 13 illustrates spatial resolution of dust "provenancing" and mapping of dust sources. Figure 13a shows dust uplift in northern Iraq leading to dust deposition event on 21 May 2009. Land cover in the region of uplift is shown as (i) overlaid by SEVIRI RGB image with pixels of approximately $5 \times 5 \mathrm{~km}$ and (ii) on a true colour image (Fig. 13b and c). The area of uplift and each pixel accommodate a number of potential sources including both seasonally dry rivers and agricultural fields. Therefore, while dust sources can theoretically be located with precision of spatial resolution of SEVIRI RGB composite images, in practice dust is mobilised from multiple erodible areas forming diffused plumes. This was also noted by Walker et al. (2009) in the analysis of uncertainties of dust source mapping in southwest Asia using MODIS. In our analysis, dust plumes can be traced back to their source areas with the highest spatial resolution of approximately $20-30 \mathrm{~km}$ in case of small-scale sources, in the absence of clouds and obscuration by dust uplifted from the upwind sources (e.g. Fig. 13) but more commonly, in case of large-scale dust plumes, with a resolution of 50-100 km (e.g. Fig. 5).

As all ice-core studies, this study analysed dust deposition events in a single point and did not address spatial variability in dust deposition. Further analysis will be required to quantify spatial variability and dust deposition rates on Mt. El-

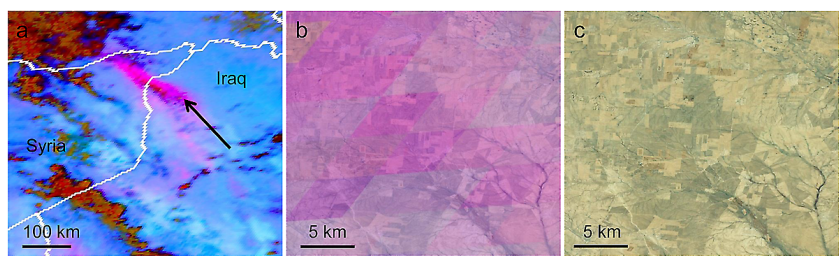

Fig. 13. (a) Dust uplift in northern Iraq. Black arrow indicates the source area. (b) The area of dust uplift shown on a surface reflectance image overlaid by SEVIRI RGB image with individual pixels seen as rectangles. (c) True-colour surface reflectance image showing multiple potential dust sources (agricultural fields, seasonally river beds) in the same area as on (b).

brus due to the influence of local topography through the extraction of multiple shallow cores in different sectors of Mt. Elbrus. Our analysis of SEVIRI imagery indicated that dust clouds passed over the southern and eastern Caucasus and these trajectories did not resulted in dust deposition on Mt. Elbrus. Thus, it will be desirable to obtain snow pit and firn or ice core records from the different regions in the Caucasus Mountains, most importantly, from the south Caucasus in the future.

\subsection{Dust source regions contributing to deposition on Mt. Elbrus}

The identified dust source areas are presented in Figs. 3 and 4. The Saharan sources are in the north of the region and their positions are in good agreement with dust source areas identified by Schepanski et al. (2009) using SEVIRI RGB imagery from 2006-2008. Dust originates mainly in the foothills of the Saharan mountains, e.g. the Djebel Akhdar in Libya and in the Ahaggar Mountains in eastern Algeria. In both regions dust emissions occur from the endorheic water systems, e.g. wadis opening to alluvial fans or chotts (dry, often salt lakes), where sediments forming through fluvial abrasion are uplifted by strong wind (Schepanski et al., 2009; Ginoux et al., 2012b). The foothills of the Atlas Mountains are another important source of dust in the northern Sahara, contributing to dust deposition in the European Alps (Collaud Coen et al., 2004), but not in the Caucasus within the period of assessment. During the dust event of 5-8 March 2009, while dust predominantly from Algeria travelled to the Caucasus, dust from the Atlas foothills crossed the Mediterranean following trajectory towards the Alps (not shown). There was no transport from the more extensive and active sources located in the southern and eastern Sahara.

The two main source regions in the Middle East are northern Mesopotamia and the Syrian Desert (Fig. 4). Active sources in northern Mesopotamia were described by Middleton $(1986,2001)$ and Wilkerson (1991). The latter study data stressed dust emissions in northeastern Syria and in southeastern but not northern Iraq. Walker et al. (2009), however, 
estimated that erodible surfaces account for $30-50 \%$ of the area in northern Mesopotamia including its Iraqi sector and making it a prominent source of dust.

In contrast to the extensive natural sources in the Sahara, multiple small-scale sources dominate in the Middle East and these are both natural (dry river beds and lakes) and anthropogenic, predominantly agricultural sources (Ginoux et al., 2012b; Walker et al., 2009). Ginoux et al. (2012b) commented that dust sources are mainly anthropogenic in northeastern Syria and natural in Iraq while Wilkerson (1991) and Gerivani et al. (2011) relate dust storms in northern Mesopotamia predominantly to the erosion of alluvial sediments. Our assessment showed a widespread occurrence of dust emissions from sources which can be characterised as anthropogenic using criteria applied by both Tegen et al. (2004), classifying land as natural if no more than $5 \%$ of regional land-use is anthropogenic, and Ginoux et al. (2012b), who applied a $30 \%$ land-use threshold to classify source regions as anthropogenic. Figure 13 illustrates dust mobilisation in northern Iraq from both agricultural and alluvial sources and during other events, dust is mobilised from a similar mixture of sources.

Greater prominence of dust emissions from anthropogenic sources in northern Mesopotamia can result from regional droughts in the 2000s. Al Dabbas et al. (2010) noted an increase in the frequency of dust storms between 1978 and 2008 in response to a negative trend in annual precipitation which declined from $138 \mathrm{~mm}$ in $1970-1979$ to $36 \mathrm{~mm}$ in 2000-2008 for six stations representing different regions of Iraq and from $327 \mathrm{~mm}$ to $149 \mathrm{~mm}$ at Mosul in northern Iraq. Reporting droughts in Syria in 2000-2010, Erian et al. (2010) stressed that eastern Syria was affected particularly strongly. In 2008, annual precipitations was about $30 \%$ below the regional forty-year average making it the driest year on record. The rain-fed crops, accounting for $71 \%$ of total arable land in Syria, cover about $8000 \mathrm{~km}^{2}$ in the region and rely on AprilMay rainfall for growth. In 2007-2010, these crops were failing in March and most of the land was abandoned and served as a source of dust (Erian et al., 2010). The desiccation of rivers was widespread including drying of the al-Khabour, a main tributary of the River Euphrates, enabling deflation of alluvial sediments in northern Mesopotamia.

Dust originating from or passing over the Middle East was characterised by the elevated concentrations of $\mathrm{NO}_{3}^{-}$ and $\mathrm{NH}_{4}^{+}$in 2009 (Table 2). Dust deposited on Mt. Elbrus on 27 June and 21 May originated from multiple sources in the Middle East including Mesopotamia (Fig. 4) while dust transport from northeastern Libya on 5 May occurred over northern Mesopotamia either causing additional uplift of dust and/or absorption of pollutants from the atmosphere (Shahgedanova et al., 2013). These results are consistent with Ginoux et al. (2012a) showed that this region is characterised by high atmospheric loads of ammonium emitted by agricultural sources and high concentrations of ammonium in dust originating from this region. By contrast, samples of the Saharan dust deposited on 8 March, showed low concentrations consistent with the low ammonium loads in the source region (Ginoux et al., 2012b). We suggest that elevated concentrations of nitrates and ammonium may serve as a tracer of dust originating from or travelling over the Middle East although analysis of larger number of samples is required to confirm this conclusion. Particle size distributions, by contrast, did not reveal any significant differences between the Saharan and the Middle Eastern sources (Figs. 8 and 9).

Data on dust mass concentrations are limited to 2009 when the average dust mass concentration was $18 \mathrm{mg} \mathrm{kg}^{-1}$ and this was strongly affected by four dust deposition events (Fig. 11). Few studies report dust mass concentrations for the short time periods (e.g. days or months) or individual events. Wake et al. (1994) reported dust mass concentrations with higher temporal resolution for eight glaciers in Central Asia. The dust mass concentrations averaged over $1-3 \mathrm{yr}$ periods were $2-8 \mathrm{mg} \mathrm{kg}^{-1}$ which is considerably lower than the average concentration in 2009 in the Caucasus.

\subsection{Seasonality of dust deposition and associated meteorological conditions}

Dust uplift and transportation to the Caucasus from both, the Sahara and the Middle East is associated with depressions migrating towards the Caucasus and occurs mainly in March-June. Dust events occurred as wet deposition and predominantly when dust-carrying depressions, producing little or no rainfall, merged with precipitation-bearing weather fronts moving from the Black Sea region.

Four Saharan events occurred within the assessment period and the frequency of 1-2 Saharan depressions per year are in agreement with the results by Hannachi et al. (2011) who estimated that on average, three Saharan depressions a year travel towards the Caucasus Mountains. Seasonality of the Saharan dust events agrees well with the studies of the formation of Saharan depressions indicating spring as the main season of their development (Hannachi et. al., 2011) and with Saharan dust events over western Europe, Mediterranean and the European Alps (Collaud Coen et al., 2004). In contrast to Mt. Elbrus, at the high altitude site Jungfraujoch in Switzerland, dust events were registered in July-August (albeit with lower frequency than in spring-early summer) and a second maximum was registered in October when only two events originating not in the Sahara but in the Middle East were recorded at Mt. Elbrus. In relation to the Saharan depressions, the difference between seasonal distributions may be attributed to the seasonal variations in activation of dust sources in the Sahara. Dust source activity in the northern Sahara moves westwards from Libya and Algeria, the main source region for the Caucasus, in March-June towards the Atlas Mountains, an important source for the European Alps, in mid-summer (Moulin et al., 1998; Schepanski et al., 2009). In spring, precipitation is low over the eastern 
Mediterranean (despite the higher frequency of the Saharan depressions which produce little rainfall) enabling efficient dust transport to the Caucasus region.

Dust transport from the Middle East is controlled by the development of low pressure systems over the Middle East - Turkey - Black Sea region and high pressure centred over or extending towards the Caspian Sea (e.g. Fig. 6) enabling the development of southerly or southeasterly flow towards the Caucasus. In March-early May and in October, westward extensions of the Siberian high dominating northern Asia in the cold half-year (Panagiotopoulos et al., 2005) develop in the north while in the second half of May-June high pressure systems forming over northern Europe prevail.

Although dust concentrations were only determined for 2009 when two of the Saharan dust events occurred (Table 2), thickness of dust layers attributed to the Saharan sources indicates higher dust loads than those associated with the Middle Eastern sources. Cyclogenesis over the North African coast, resulting in dust transportation, was intense with central SLP in depressions as low as $979 \mathrm{hPa}$ while the depressions forming over the Middle Eastern were less vigorous with central SLP of 1000-1008 hPa. Surface wind speeds over the Saharan source regions reached $20 \mathrm{~m} \mathrm{~s}^{-1}$ and daily $700 \mathrm{hPa}$ wind speeds averaged $20-30 \mathrm{~m} \mathrm{~s}^{-1}$ against $12-$ $18 \mathrm{~m} \mathrm{~s}^{-1}$ during the dust transport from the Middle East. Strong ascent, with vertical velocities in access of $0.2 \mathrm{~m} \mathrm{~s}^{-1}$, induced by frontal systems characterises the Saharan depressions and this is considerably weaker over the Middle East.

\section{Conclusions}

A four-year record of desert dust deposition events, derived from a snow pit and a shallow firn core, encompassing the 2009-2012 period was for the first time presented for the Caucasus Mountains, Russia. The elevation and climatic characteristics of Mt. Elbrus made it ideal for trapping and preserving dust in snow and firn. The application of a multi-disciplinary methodology based on the analysis of high-resolution remote-sensing products from SEVIRI and MODIS, back trajectory models and meteorological data for the first time allowed dating and "provenancing" dust events with temporal precision of days or hours and spatial resolution of 20-100 km. The main source regions of dust were the northern Sahara (especially northeastern Libya and Algeria), the Syrian Desert and northern Mesopotamia. Despite the frequent comments, made in the Russian-language literature on the dust transport from the deserts of Kazakhstan, Central Asia and lower Volga, we found no such events within the assessment period most likely due to the absence of meteorological conditions for dust transport from this region at high elevations. Most dust deposition events occurred in March-June, but also in February and October, and were associated with either vigorous Saharan depressions or with southerly flow from the Middle East forming between the de- pressions over the source region moving towards the Caucasus and high pressure systems extending towards the Caspian Sea. The first type of events was less frequent but associated with deeper depressions and stronger air flow and resulted in higher dust loads. The second type was more frequent but associated with weaker deposition. In both cases, wet deposition occurred when the dust-bearing air masses merged with precipitation-bearing weather fronts advancing towards the Caucasus from the Black Sea - Turkey region.

Due to the logistical reasons, dust mass and concentrations of soluble ions in snow were determined for 2009 only which is a limitation of this study. However, analysis of the 2009 events revealed higher concentrations of nitrates and ammonium in the samples attributed to the Middle Eastern sources than in the sample attributed to the Sahara potentially indicating the input of anthropogenic sources in the Middle East either at the point of emission (i.e. fertilizers used on agricultural fields) or during the transportation over this populated region. Comparison of the Middle Eastern sources contributing to the analysed dust events with their assessments published in literature (e.g. Walter et al., 2009; Wilkerson, 1991) showed that the prominence of northern Mesopotamia as a source region of dust might have increased during the period of assessment in comparison with the earlier years due to the drought observed in Syria and Iraq in the 2000s. A more detailed, quantitative assessment of input of anthropogenic sources of dust to deposition events and impacts of climatic variability on dust emissions requires chemical analysis of larger number of dust samples and a longer record. A deeper core has been extracted on Mt. Elbrus in the summer of 2013 and will provide more information on total dust deposition, chemical properties of dust, and comparison between the anomalously dry years with those when precipitation was close to its climatological norm in the Middle East.

Acknowledgements. The research leading to these results has received funding from the European Union Seventh Framework Programme FP7-PEOPLE-2010-IIF under grant agreement PIIF-GA-2010-275071, Royal Society International Joint Project "Impacts of Dust Deposition on Glacier Melt in the Caucasus Mountains, Russia" (project N JP100235) and Russian Foundation for Basic Research (grants 11-05-00304 and 13-05-10069). The University of Reading UROP scheme funded SEM analysis. We are grateful to the Climate and Environment Research Laboratory (CERL), Arctic and Antarctic Research Institute, St. Petersburg, Russia for isotopic analysis and the University of Reading Centre for Advanced Microscopy for providing access to and help with SEM. We thank Nigel Cameron, Environmental Change Research Centre, University College London for classifying diatoms and Kevin White, Department of Geography and Environmental Science, University of Reading for sharing his vast knowledge of geomorphology of the Sahara and deserts of the Middle East.

Edited by: G. Winckler 


\section{References}

Al-Dabbas, M. A., Ayad Abbas, M., and Al-Khafaji, R. M.: Dust storms loads analyses - Iraq, Arab. J. Geosci., 5, 121-131, doi:10.1007/s12517-010-0181-7, 2010.

Banks, J. R. and Brindley, H. E.: Evaluation of MSGSEVIRI mineral dust retrieval products over North Africa and the Middle East, Remote Sens. Environ., 128, 58-73, doi:10.1016/j.rse.2012.07.017, 2013.

Barkan, J., Alpert, P., Kutiel, H., and Kishcha, P.: Synoptics of dust transportation days from Africa toward Italy and central Europe, J. Geophys. Res., 110, D07208, doi:10.1029/2004JD005222, 2005.

Bou Karam, D., Flamant, C., Cuesta, J., Pelon, J., and Williams, E.: Dust emission and transport associated with a Saharan depression: February 2007 case, J. Geophys. Res., 115, D00H27, doi:10.1029/2009JD012390, 2010.

Brindley, H. E. and Russell, J. E.: An assessment of Saharan dust loading and the corresponding cloud-free longwave direct radiative effect from geostationary satellite observations, J. Geophys. Res., 114, D23201, doi:10.1029/2008JD011635, 2009.

Brindley, H., Knippertz, P., Ryder, C., and Ashpole, I.: A critical evaluation of the ability of the Spinning Enhanced Visible and Infrared Imager (SEVIRI) thermal infrared red-green-blue rendering to identify dust events: Theoretical analysis, J. Geophys. Res., 117, D07201, doi:10.1029/2011JD017326, 2012.

Castillo, S., Moreno, T., Querol, X., Alastuey, A., Cuevas, E., Herrmann, L., Mounkaila, M., and Gibbons, W.: Trace element variation in size-fractionated African desert dusts, J. Arid Environ., 72, 1034-1045, doi:10.1016/j.jaridenv.2007.12.007, 2008.

Chomette, O., Legrand, M., and Marticorena, B.: Determination of the wind speed threshold for the emission of desert dust using satellite remote sensing in the thermal infrared, J. Geophys. Res., 104, 31207, doi:10.1029/1999JD900756, 1999.

Christopher, S. A., Gupta, P., Johnson, B., Ansell, C., Brindley, H., and Haywood, J.: Multi-sensor satellite remote sensing of dust aerosols over North Africa during GERBILS, Q. J. Roy. Meteor. Soc., 137, 1168-1178, doi:10.1002/qj.863, 2011.

Collaud Coen, M., Weingartner, E., Schaub, D., Hueglin, C., Corrigan, C., Henning, S., Schwikowski, M., and Baltensperger, U.: Saharan dust events at the Jungfraujoch: detection by wavelength dependence of the single scattering albedo and first climatology analysis, Atmos. Chem. Phys., 4, 2465-2480, doi:10.5194/acp4-2465-2004, 2004.

De Angelis, M. and Gaudichet, A.: Saharan dust deposition over Mont Blanc (French Alps) during the last 30 years, Tellus B, 43, 61-75, doi:10.1034/j.1600-0889.1991.00005.x, 1991.

Delmonte, B., Petit, J.-R., and Maggi, V.: Glacial to Holocene implications of the new 27000-year dust record from the EPICA Dome C (East Antarctica) ice core, Clim. Dynam., 18, 647-660, doi:10.1007/s00382-001-0193-9, 2002.

Dong, Z. and Li, Z.: Characteristics of Atmospheric Dust Deposition in Snow on Glacier No. 72, Mount Tuomuer, China, Arct. Antarct. Alp. Res., 43, 517-526, doi:10.1657/1938-424643.4.517, 2011.

Dong, Z., Li, Z., Wang, F., and Zhang, M.: Characteristics of atmospheric dust deposition in snow on the glaciers of the eastern Tien Shan, China, J. Glaciol., 55, 797-804, doi:10.3189/002214309790152393, 2009.
Draxler, R. R. and Rolph, G. D.: HYSPLIT (HYbrid Single-Particle Lagrangian Integrated Trajectory) Model access via NOAA ARL READY Website (http://ready.arl.noaa.gov/HYSPLIT. php), NOAA Air Resources Laboratory, Silver Spring, MD, 2013.

Erian, W., Katlan, B., and Babah, O.: Drought vulnerability in the Arab region: Special case study: Syria, Background paper prepared for the 2011 Global Assessment Report on Disaster Risk Reduction, Geneva, Switzerland, 2010.

Formenti, P., Elbert, W., Maenhaut, W., Haywood, J., and Andreae, M. O.: Chemical composition of mineral dust aerosol during the Saharan Dust Experiment (SHADE) airborne campaign in the Cape Verde region, September 2000, J. Geophys. Res., 108, 8576, doi:10.1029/2002JD002648, 2003.

Gerivani, H., Lashkaripur, G., Ghafoori, M., and Jalili, N.: The source of dust storm in Iran: a case study based on geological information and rainfall data, Carpath. J. Earth Env., 6, 297-308, 2011.

Ginoux, P., Clarisse, L., Clerbaux, C., Coheur, P.-F., Dubovik, O., Hsu, N. C., and Van Damme, M.: Mixing of dust and $\mathrm{NH}_{3}$ observed globally over anthropogenic dust sources, Atmos. Chem. Phys., 12, 7351-7363, doi:10.5194/acp-12-7351-2012, $2012 \mathrm{a}$.

Ginoux, P., Prospero, J., Gill, T., Hsu, N., and Zhao, M.: Globalscale attribution of anthropogenic and natural dust sources and their emission rates based on MODIS Deep Blue aerosol products, Rev. Geophys., 50, RG3005, doi:10.1029/2012RG000388, 2012 b.

Grousset, F. E. Ginoux, P., Bory, A., and Biscaye, P. E.: Case study of a Chinese dust plume reaching the French Alps, Geophys. Res. Lett., 30, 1277, doi:10.1029/2002GL016833, 2003.

Guieu, C., Loÿe-Pilot, M.-D., Ridame, C., and Thomas, C.: Chemical characterisation of the Saharan dust end-member: Some biogeochemical implications for the western Mediterranean Sea, J. Geophys. Res., 107, 4258, doi:10.1029/2001JD000582, 2002.

Hannachi, A., Awad, A., and Ammar, K.: Climatology and classification of Spring Saharan cyclone tracks, Clim. Dynam., 37, 473-491, doi:10.1007/s00382-010-0941-9, 2011.

Hsu, N. C., Tsay, S.-C., King, M. D., and Herman, J. R.: Aerosol Properties Over Bright-Reflecting Source Regions, IEEE T. Geosci. Remote, 42, 557-569, doi:10.1109/TGRS.2004.824067, 2004.

Hsu, N. C., Tsay, S.-C., King, M. D., and Herman, J. R.: Deep Blue Retrievals of Asian Aerosol Properties During ACE-Asia, IEEE T. Geosci. Remote, 44, 3180-3195, doi:10.1109/TGRS.2006.879540, 2006.

Kalnay, E., Kanamitsu, M., Kistler, R., Collins, W., Deaven, D., Gandin, L., Iredell, M., Saha, S., White, G., Woollen, J., Zhu, Y., Leetmaa, A., Reynolds, R., Chelliah, M., Ebisuzaki, W., Higgins, W., Janowiak, J., Mo, K. C., Ropelewski, C., Wang, J., Jenne, R., and Joseph, D.: The NCEP/NCAR 40-Year Reanalysis Project, B. Am. Meteorol. Soc., 77, 437-471, doi:10.1175/15200477(1996)077<0437:TNYRP>2.0.CO;2, 1996.

Kaspari, S., Mayewski, P. a., Handley, M., Kang, S., Hou, S., Sneed, S., Maasch, K., and Qin, D.: A High-Resolution Record of Atmospheric Dust Composition and Variability since a.d. 1650 from a Mount Everest Ice Core, J. Climate, 22, 3910-3925, doi:10.1175/2009JCLI2518.1, 2009.

Knippertz, P. and Todd, M. C.: Mineral dust aerosols over the Sahara: Meteorological controls on emission and transport 
and implications for modeling, Rev. Geophys., 50, RG1007, doi:10.1029/2011RG000362, 2012.

Koçak, M., Theodosi, C., Zarmpas, P., Séguret, M. J. M., Herut, B., Kallos, G., Mihalopoulos, N., Kubilay, N., and Nimmo, M.: Influence of mineral dust transport on the chemical composition and physical properties of the Eastern Mediterranean aerosol, Atmos. Environ., 57, 266-277, doi:10.1016/j.atmosenv.2012.04.006, 2012.

Kokkalis, P., Mamouri, R. E., Todua, M., Didebulidze, G. G., Papayannis, A., Amiridis, V., Basart, S., Pérez, C., and Baldasano, J. M.: Ground-, satellite- and simulation-based analysis of a strong dust event over Abastumani, Georgia, during May 2009, Int. J. Remote Sens., 33, 4886-4901, doi:10.1080/01431161.2011.644593, 2012.

Kreutz, K. J., Aizen, V. B., Cecil, L. D., and Wake, C. P.: Oxygen isotopic and soluble ionic composition of a shallow firn core, Inilchek glacier, central Tien Shan, J. Glaciol., 47, 548554, doi:10.3189/172756501781831819, 2001.

Legrand, M. and Mayewski, P.: Glaciochemistry of polar ice cores: A review, Rev. Geophys., 35, 219-243, doi:10.1029/96RG03527, 1997.

Lensky, I. M. and Rosenfeld, D.: Clouds-Aerosols-Precipitation Satellite Analysis Tool (CAPSAT), Atmos. Chem. Phys., 8, 6739-6753, doi:10.5194/acp-8-6739-2008, 2008.

Middleton, N. J.: Dust storms in the Middle East, J. Arid Environ., 10, 83-96, 1986.

Middleton, N. J. and Goudie, A. S.: Saharan dust: sources and trajectories, T. I. Brit. Geogr., 26, 165-181, doi:10.1111/14755661.00013, 2001.

Mikhalenko, V. N., Kutuzov, S. S., Lavrentiev, I. I., Kunakhovich, M. G., Tompson, L. G.: Elbrus western firn plateau studies: results and prospects, Data Glaciol. Studies, 99, 185-190, 2005 (in Russian).

Moulin, C., Lambert, C. E., Dayan, U., Masson, V., Ramonet, M., Bousquet, P., Legrand, M., Balkanski, Y. J., Guelle, W., Marticorena, B., Bergametti, G., and Dulac, F.: Satellite climatology of African dust transport in the Mediterranean atmosphere, J. Geophys. Res., 103, 13137, doi:10.1029/98JD00171, 1998.

Olivier, S.: Glaciochemical investigation of an ice core from Belukha glacier, Siberian Altai, Geophys. Res. Lett., 30, 2019, doi:10.1029/2003GL018290, 2003.

Olivier, S., Blaser, C., Brütsch, S., Frolova, N., Gäggeler, H. W., Henderson, K. a., Palmer, a. S., Papina, T., and Schwikowski, M.: Temporal variations of mineral dust, biogenic tracers, and anthropogenic species during the past two centuries from Belukha ice core, Siberian Altai, J. Geophys. Res., 111, D05309, doi:10.1029/2005JD005830, 2006.

Osada, K., Iida, H., Kido, M., Matsunaga, K., and Iwasaka, Y.: Mineral dust layers in snow at Mount Tateyama, Central Japan: formation processes and characteristics, Tellus B, 56, 382-392, doi:10.1111/j.1600-0889.2004.00108.x, 2004.

Panagiotopoulos, F., Shahgedanova, M., Hannachi, A., and Stephenson, D. B.: Observed Trends and Teleconnections of the Siberian High: A Recently Declining Center of Action, J. Climate, 18, 1411-1422, doi:10.1175/JCLI3352.1, 2005.

Petit, J. R., Jouzel, J., Raynaud, D., Barkov, N. I., Barnola, J. M., Basile, I., Bender, M., Chappellaz, J., Davis, M., Delaygue, G., Delmotte, M., Kotlyakov, V. M., Legrand, M., Lipenkov, V. Y., Lorius, C., Pépin, L., Ritz, C., Saltzman, E., and Stievenard,
M.: Climate and atmospheric history of the past 420,000 years from the Vostok ice core, Antarctica, Nature, 399, 429-436, doi:10.1038/20859, 1999.

Pierangelo, C., Chédin, A., Heilliette, S., Jacquinet-Husson, N., and Armante, R.: Dust altitude and infrared optical depth from AIRS, Atmos. Chem. Phys., 4, 1813-1822, doi:10.5194/acp-41813-2004, 2004.

Reid, J. S., Jonsson, H. H., Maring, H. B., Smirnov, A., Savoie, D. L., Cliff, S. S., Reid, E. A., Livingston, J. M., Meier, M. M., Dubovik, O., and Tsay, S. C.: Comparison of size and morphological measurements of coarse mode dust particles from Africa, J. Geophys. Res., 108, 8593, doi:10.1029/2002JD002485, 2003.

Roebeling, R. A., Wolters, E. L. A., Meirink, J. F., and Leijnse, H.: Triple Collocation of Summer Precipitation Retrievals from SEVIRI over Europe with Gridded Rain Gauge and Weather Radar Data, J. Hydrometeorol., 13, 1552-1566, doi:10.1175/JHM-D11-089.1, 2012.

Rototaeva, O. V., Khmelevskoy, I. F., Bazhev, A. B., Hetzimberg, J., Stenberg, M., and Pinglot, J. F.: Structure and chemical composition of the Bolshoy Azau glacier active layer, Data Glaciol. Studies, 84, 25-33, 1998 (in Russian).

Rototaeva, O. V., Kerimov, A. M., and Khmelevskoy, I. F.: Macrochemical composition of Elbrus southern slope glaciers, Data Glaciol. Studies, 87, 98-105, 1999 (in Russian).

Ruth, U., Wagenbach, D., Steffensen, J. P., and Bigler, M.: Continuous record of microparticle concentration and size distribution in the central Greenland NGRIP ice core during the last glacial period, J. Geophys. Res., 108, 4098, doi:10.1029/2002JD002376, 2003.

Schepanski, K., Tegen, I., Laurent, B., Heinold, B., and Macke, A.: A new Saharan dust source activation frequency map derived from MSG-SEVIRI IR-channels, Geophys. Res. Lett., 34, L18803, doi:10.1029/2007GL030168, 2007.

Schepanski, K., Tegen, I., Todd, M. C., Heinold, B., Bönisch, G., Laurent, B., and Macke, A.: Meteorological processes forcing Saharan dust emission inferred from MSG-SEVIRI observations of subdaily dust source activation and numerical models, J. Geophys. Res., 114, D10201, doi:10.1029/2008JD010325, 2009.

Schwikowski, B. M., Doscher, A., Gaggeler, H. W., and Schotterer, U.: Anthropogenic versus natural sources of atmospheric sulphate from an Alpine ice core, Tellus B, 51, 938-951, doi:10.1034/j.1600-0889.1999.t01-4-00006.x, 1999.

Schwikowski, M., Seibert, P., Baltensperger, U., and Gaggeler, H. W.: A study of an outstanding Saharan dust event at the high-alpine site Jungfraujoch, Switzerland, Atmos. Environ., 29, 1829-1842, doi:10.1016/1352-2310(95)00060-C, 1995.

Shahgedanova, M., Kutuzov, S., White, K. H., and Nosenko, G.: Using the significant dust deposition event on the glaciers of Mt. Elbrus, Caucasus Mountains, Russia on 5 May 2009 to develop a method for dating and "provenancing" of desert dust events recorded in snow pack, Atmos. Chem. Phys., 13, 1797-1808, doi:10.5194/acp-13-1797-2013, 2013.

Sodemann, H., Palmer, A. S., Schwierz, C., Schwikowski, M., and Wernli, H.: The transport history of two Saharan dust events archived in an Alpine ice core, Atmos. Chem. Phys., 6, 667-688, doi:10.5194/acp-6-667-2006, 2006.

Steffensen, J. P.: The size distribution of microparticles from selected segments of the Greenland Ice Core Project ice core repre- 
senting different climatic periods, J. Geophys. Res., 102, 26755, doi:10.1029/97JC01490, 1997.

Stokes, C. R., Gurney, S. D., Shahgedanova, M., and Popovnin, V.: Late-20th-century changes in glacier extent in the Caucasus Mountains, Russia/Georgia, J. Glaciol., 52, 99-109, doi:10.3189/172756506781828827, 2006.

Tegen, I., Werner, M., Harrison, S. P., and Kohfeld, K. E.: Relative importance of climate and land use in determining present and future global soil dust emission, Geophys. Res. Lett., 31, L05105, doi:10.1029/2003GL019216, 2004.

Thevenon, F., Anselmetti, F. S., Bernasconi, S. M., and Schwikowski, M.: Mineral dust and elemental black carbon records from an Alpine ice core (Colle Gnifetti glacier) over the last millennium, J. Geophys. Res., 114, D17102, doi:10.1029/2008JD011490, 2009.

Thevenon, F., Chiaradia, M., Adatte, T., Hueglin, C., and Poté, J.: Characterisation of Modern and Fossil Mineral Dust Transported to High Altitude in the Western Alps: Saharan Sources and Transport Patterns, Adv. Meteorol., 2012, 674385, doi:10.1155/2012/674385, 2012.

Thompson, L. G., Mosley-Thompson, E., Davis, M. E., Bolzan, J. F., Dai, J., Klein, L., Yao, T., Wu, X., Xie, Z., and Gundestrup, N.: Holocene-late Pleistocene climatic ice core records from Qinghai-Tibetan plateau, Science (New York, N.Y.), 246, 474-477, doi:10.1126/science.246.4929.474, 1989.

Thompson, L. G., Mosley-Thompson, E., Brecher, H., Davis, M., León, B., Les, D., Lin, P.-N., Mashiotta, T., and Mountain, K.: Abrupt tropical climate change: Past and present, P. Natl. Acad. Sci. USA, 103, 10536-10543, doi:10.1073/pnas.0603900103, 2006.

Vinogradov, A. N.: The geochemistry of rare and dispersed chemical elements in soils, 2nd Edn., Consult. Bur., New York, 1959.

Wagenbach, D. and Geis, K.: The mineral dust concentrations and depositions of sulphur in Europe record in a high altitude glacier (Colle Gnifetti, Swiss Alps), in: Paleoclimatology and paleometeorology: modern and past patterns of global atmospheric transport, edited by: Leinen, M. and Sarnthein, M., Kluwer Academic Publishers, Dordrecht, 543-564, 1989.
Wake, C. P., Mayewski, P. A., Li, Z., Han, J., and Qin, D.: Modern eolian dust deposition in central Asia, Tellus B, 46, 220-233, doi:10.1034/j.1600-0889.1994.t01-2-00005.x, 1994.

Walker, A. L., Liu, M., Miller, S. D., Richardson, K. A., and Westphal, D. L.: Development of a dust source database for mesoscale forecasting in southwest Asia, J. Geophys. Res., 114, D18207, doi:10.1029/2008JD011541, 2009.

Wilkerson W. D.: Dust and Sand Forecasting in Iraq and Adjoining Countries, Technical Report, Air Weather Service, Scott AFB (AWS/XTX), IL 62225-5008.

Winker, D. M., Pelon, J. R., and McCormick, M. P.: The CALIPSO mission: spaceborne lidar for observation of aerosols and clouds, in Proc. SPIE 4893, Lidar Remote Sensing for Industry and Environment Monitoring III, 1 (24 March 2003), 1-11, 2003.

Wu, G., Yao, T., Xu, B., Tian, L., Zhang, C., and Zhang, X.: Volume-size distribution of microparticles in ice cores from the Tibetan Plateau, J. Glaciol., 55, 859-868, doi:10.3189/002214309790152492, 2009.

Wu, G., Zhang, C., Xu, B., Mao, R., Joswiak, D., Wang, N., and Yao, T.: Atmospheric dust from a shallow ice core from Tanggula: implications for drought in the central Tibetan Plateau over the past 155 years, Quat. Sci. Rev., 59, 57-66, doi:10.1016/j.quascirev.2012.10.003, 2013.

Xu, J., Hou, S., Qin, D., Kaspari, S., Mayewski, P. A., Petit, J. R., Delmonte, B., Kang, S., Ren, J., Chappellaz, J., and Hong, S.: A 108.83-m ice-core record of atmospheric dust deposition at Mt. Qomolangma (Everest), Central Himalaya, Quaternary Res., 73, 33-38, doi:10.1016/j.yqres.2009.09.005, 2010.

Yang, M., Yao, T., and Wang, H.: Microparticle content records of the Dunde ice core and dust storms in northwestern China, J. Asian Earth Sci., 27, 223-229, doi:10.1016/j.jseaes.2005.03.007, 2006. 